\title{
MEMORANDUM
}

No $07 / 2003$

\section{Assimilation Effects on Poverty Among Immigrants in} Norway

$$
\text { By }
$$

Taryn Ann Galloway and Rolf Aaberge

\section{Department of Economics University of Oslo}


This series is published by the

University of Oslo Department of Economics

P. O.Box 1095 Blindern

N-0317 OSLO Norway

Telephone: +4722855127

Fax: $\quad+4722855035$

Internet: http://www.oekonomi.uio.no/

e-mail: $\quad \underline{\text { econdep } @ \text { econ.uio.no }}$
In co-operation with

The Frisch Centre for Economic Research

Gaustadalleén 21

N-0371 OSLO Norway

Telephone: $\quad+4722958820$

Fax: $\quad+4722958825$

Internet: $\quad$ http://www.frisch.uio.no/

e-mail: $\quad$ frisch@,frisch.uio.no

List of the last 10 Memoranda:

\begin{tabular}{|ll|l|}
\hline No & 06 & $\begin{array}{l}\text { Geir B. Asheim } \\
\text { Green national accounting with a changing population. } 23 \text { pp. }\end{array}$ \\
\hline No & 05 & $\begin{array}{l}\text { Geir B. Asheim and Ylva Søvik } \\
\text { The semantics of preference-based belief operators. } 30 \text { pp.Rolf }\end{array}$ \\
\hline No & 04 & $\begin{array}{l}\text { Zhiyang Jia } \\
\text { A Mixture Model of Household Retirement Choice. } 21 \mathrm{pp} .\end{array}$ \\
\hline No & 03 & $\begin{array}{l}\text { Erling Eide } \\
\text { Optimal Provision of Public Goods with Rank Dependent Expected. } \\
\text { tility. 21 pp. }\end{array}$ \\
\hline No & 02 & $\begin{array}{l}\text { Hilde C. Bjørnland } \\
\text { Estimating the equilibrium real exchange rate in Venezuela. pp. }\end{array}$ \\
\hline No & 01 & $\begin{array}{l}\text { Svenn-Erik Mamelund } \\
\text { Can the Spanish Influenza pandemic of 1918 explain the baby-boom of } \\
\text { 1920 in neutral Norway?. 33 pp. }\end{array}$ \\
\hline No 36 & $\begin{array}{l}\text { Elin Halvorsen } \\
\text { A Cohort Analysis of Household Saving in Norway. 39 pp. }\end{array}$ \\
\hline No 35 & $\begin{array}{l}\text { V. Bhaskar and Steinar Holden } \\
\text { Wage Differentiation via Subsidised General Training. 24 pp. }\end{array}$ \\
\hline No 34 & $\begin{array}{l}\text { Cathrine Hagem and Ottar Mæstad } \\
\text { Market power in the market for greenhouse gas emissions permits - the } \\
\text { interplay with the fossil fuel markets. 21pp. }\end{array}$ \\
\hline No 33 & $\begin{array}{l}\text { Cees Withagen, Geir B. Asheim and Wolfgang Buchholz } \\
\text { On the sustainable program in Solow's model. 11 pp. }\end{array}$ \\
\hline
\end{tabular}

A complete list of this memo-series is available in a PDF® format at: http://www.oekonomi.uio.no/memo/ 


\title{
Assimilation Effects on Poverty Among Immigrants in Norway $^{1}$
}

\author{
Taryn Ann Galloway
}

Research Department, Statistics Norway, Postboks 8131 Dep, 0033 Oslo, Norway

Fax: +47 2109 0040, e-mail: tag@ssb.no

\section{Rolf Aaberge}

Research Department, Statistics Norway, Postboks 8131 Dep, 0033, Oslo, Norway and Ragnar Frisch Centre for Economic Research

Fax: +47 210900 40, e-mail: roa@ssb.no

\begin{abstract}
This paper discusses the question of whether or not the high incidence of poverty among immigrants in Norway persists even after immigrants have been in the country for a long period, that is, after they have had the opportunity to integrate and adapt their skills to the expectations in their new home. While similar to traditional studies of wage assimilation, a study of assimilation in relation to poverty propensity nevertheless measures something different than labor market assimilation, and this represents the main innovation of this study. Analysis of assimilation with respect to poverty focuses on welfare for the lower end of the income distribution and for all individuals, regardless of their relationship with the labor market. It can therefore be seen to better reflect the degree to which immigrants as a whole are able to achieve at least the minimum necessary to participate in the life of their new home and avoid difficulties later on.
\end{abstract}

Key words: Immigration, assimilation, poverty

\section{JEL Classification: I 32}

Acknowledgement: We would like to thank Lars Østby as well as two anonymous referees for helpful comments. This research was supported by the Norwegian Ministry of Labour and Government Administration. Ms Galloway was employed at the Ragnar Frisch Centre for Economic Research during the period when the article was written.

\footnotetext{
${ }^{1}$ Correspondence can be sent to Ms Galloway
} 


\section{Introduction}

Norway has long been regarded as a rich welfare state with relatively low income inequality and would therefore hardly seem the likely object for a study of poverty. However, a certain proportion of the Norwegian population does have a level of income so far below that of the rest of the population that participation in societal life most certainly is impaired. In some respects, the persistence of poverty in a country such as Norway can help us to isolate some of the particularly intractable factors which allow poverty to exist even in affluent welfare states. The percentage of poor among immigrants in Norway is much larger than the percentage in the native population so that immigrant status and ethnic origin may just help to explain to some degree the continuing existence of poverty in the country. However, the more crucial question is whether or not this rather high incidence of poverty among immigrants persists even after immigrants have been in the country for a long period, that is, after they have had the opportunity to integrate and adapt their skills to the expectations in their new home.

If one considers both an immigrant's initial adjustment difficulties and the different demographic composition of the immigrant population as compared to the native population, a difference in the likelihood for poverty in the immigrant and native population hardly seems surprising. If one can control for some major demographic differences, such as household composition, age and education, one would expect that an immigrant's probability of being poor would be lower after he or she had been in the country for several years and had therefore been able to adapt and adjust to his or her new environment. One might even expect that, after a sufficiently long period of adaptation and integration, immigrants' probability for poverty would converge to the level of the native population with the same or very similar demographic characteristics.

A large number of labor market studies have addressed the issue of the wage assimilation of foreigners relative to native workers. Chiswick (1978) was the first to analyze wage assimilation for immigrants in the US and was able to discern a positive relationship between years in the country and wages relative to natives, but later studies have introduced various refinements on that main model. In particular, results in Borjas (1985) suggest that cross-sectional analysis, such as in Chiswick (1978), need not imply wage assimilation, but might rather be indicative of a decline in cohort quality among successive immigrant groups. The analysis in Borjas (1985) relies, in turn, on an implicit assumption of equal period effects for all immigrant cohorts, in 
other words, that the effects of economic conditions were the same for natives and various immigrant cohorts during the entire period of investigation. A forthcoming Norwegian study (Barth, Bratsberg and Raaum (2004)) discusses how such an assumption can introduce biases in the measure of assimilation as well as cohort quality and introduces differential period effects embodied by local labor market conditions (unemployment) for immigrant and natives. That study indicates that failure to take into consideration different period effects results in an overestimation of differences in cohort quality as well as underestimation of wage assimilation for nonOECD immigrants in Norway. While all of these refinements have resulted in differences in the interpretation of the extent to which wage assimilation has occurred, they do not reverse the general finding that some assimilation does in fact take place.

A certain degree of wage assimilation for foreigners in Norway has therefore been suggested by previous studies ${ }^{2}$ and such studies certainly give rise to expectations of a similar assimilation effect with regards to poverty. There are, however, some major differences between studies of wage assimilation and poverty that should be noted. Firstly, wage assimilation studies focus on the labor market success of individuals. The labor market difficulties of immigrants are hardly a new tale, so focusing on wages alone does not give us a complete picture of the welfare situation for immigrants without regular work. It also fails to take into account welfare issues for household members that do not participate in the labor market. In other words, wage assimilation does not provide us with the whole picture, because it leaves out many relevant variables, such as household composition and the actual number of wage earners in the household. Secondly, increasing success in escaping poverty does not have to mean that a large degree of wage assimilation has taken place nor that wage assimilation is the only cause of the decrease in poverty. It could be due to improved access to welfare programs or better access to low-paying jobs that nonetheless provide income just over the poverty line. While studying wage assimilation is very important for establishing the extent to which immigrants are able to improve their situation by their own means when they find employment, assimilation with respect to poverty propensity helps to establish the extent to which immigrants are able to avoid very low income in a manner similar to the native population.

Another phenomenon relevant in this context is assimilation with regards to

\footnotetext{
${ }^{2}$ Hayfron (1998) and Longvå and Raaum (2002) as well as the forthcoming paper by Barth, Bratsberg
} 
participation in social assistance (welfare) programs or other forms of transfers, a topic which has started to gain some attention within the last decade. It may not be entirely clear just what assimilation means in such a context. If immigrants start out at a lower level of welfare participation than the native population, would assimilation mean increased participation over time or does assimilation mean that immigrants' are less reliant on welfare, regardless of how they compare to the native population? The crucial question in the literature seems to be whether higher or lower participation rates occur over time. Hansen and Lofstrom (2003) elegantly solve this semantic difficulty by speaking of increased participation over time as "assimilation into welfare" and decreased participation as "assimilation out of welfare". In fact, Hansen and Lofstrom need to make this distinction because their findings for Sweden, which suggest assimilation out of welfare, are the exact opposite of previous findings for the US and Canada $^{3}$. Although similar studies have yet to appear for Norway, similarities to Sweden politically and economically as well as very basic descriptive analysis of immigrants' income makes assimilation out of welfare also seem likely in Norway. ${ }^{4}$

Finally, welfare or social assistance is just one aspect of the social safety net in modern welfare economies. Participation in social insurance based on rights typically acquired by paying into the social insurance system over time is another area in which immigrants can become more similar, i.e. assimilate, to their native counterparts. Data for Norway, for example, indicate that there are proportionally fewer immigrants on disability insurance than in the general Norwegian population. However, the percentage of immigrants with disability insurance does increase with the time spent in the country, first and foremost due to larger numbers of immigrants acquiring the rights to such benefits through employment after several years in the country (Dahl, 2002).

A study of assimilation with respect to poverty propensity simply measures something different than labor market assimilation. It focuses on welfare for the lower end of the income distribution and for all individuals, regardless of their relationship with the labor market or the social insurance system. In end effect it combines elements from both studies of welfare participation and studies of wage assimilation, but, more importantly, it reflects the degree to which immigrants as a whole are able to

and Raaum (2004) provide results from Norway.

${ }^{3}$ See Borjas and Trejo (1991) and Borjas and Hilton (1996) for analysis of the US and Baker and Benjamin (1995) for results from Cananda.

${ }^{4}$ Lie (2002), pp. 83-95, gives an overview of immigrants' income components, also relative to their time in the country. 
achieve at least the minimum necessary to participate in the life of their new home and avoid potential difficulties later on. This crucial distinction represents the main innovation of our approach. By having a look at how immigrants are faring with respect to a certain minimum in the society, we can better establish the extent to which more specific policies and programs with respect to immigration in general, labor market assimilation, social insurance or even welfare are needed.

While the well-being of today's immigrants appears to have its own place besides efficiency arguments in the general immigration debate in Norway, there is also an efficiency aspect involved in maintaining the welfare of immigrants. Immigrant groups with a persistently high probability of poverty, i.e. a lack of assimilation with respect to poverty probabilities over time, may bring with them any of a number of social woes generally associated with poverty for any group, native or immigrant, be it depressed neighborhoods, increased crime, stigmatization or social unrest.

The paper is organized as follows. The next section provides a basic overview of the data, definitions and methods used to measure poverty in this study. It is followed by a section that gives a general picture of developments in immigration to Norway as well as the prevalence of poverty among immigrants to Norway by ethnic origin. The discussion in that section indicates the need for the more detailed logistic regression analysis presented in Section 4. That analysis focuses on the question of the impact of integration, measured very roughly as the number of years since migration, on the probability of being poor. The analysis based on annual income is also supplemented by an analysis of the situation with income over a three-year period. The final section, Section 5, discusses the findings, suggests possible interpretation and addresses some of the shortcomings and challenges presented by the analysis.

\section{Definitions, Methods and Data}

Construction of the relative poverty line used here was based on official data from the Norwegian national statistical office, Statistics Norway, and encompasses the entire resident population of Norway in each of the years 1995-1997. More specifically, we use a poverty line given at $50 \%$ of median equivalent income after tax for the entire population in the relevant time period (one or three years) as described in more detail below. The logistic regressions performed later on in this paper to model immigrants' and natives' probabilities of poverty include only working age (16-68 years) persons who were not in education, but the classification as poor was based on 
calculations with the entire population. The main reason behind excluding groups such as the elderly, children and students lies with the fact that the income for these groups are determined by forces far different than those of the working age populations, i.e. the pension system, parents' income, and education grants and loans. The income level of such groups is relevant in establishing a measure of the general income situation in the population, so they are included when determining the poverty line, but the different forces influencing their income level would present complications in isolating the effects of assimilation. These groups require a separate and very different approach if one wants to address the issue of their assimilation with respect to poverty.

Use of data from the entire working age population of Norway makes it possible to obtain more reliable information than survey data, especially with regards to small groups. Survey data on groups that make up just a small portion of the population entail a large degree of uncertainty with respect to statistical results, and thus the ability to interpret any such results with confidence can be severely impaired. This is all the more true for immigrants, especially if one does not wish to treat them as a homogenous group, but would rather distinguish between immigrants of different ethnic origin, as we intend to do here.

Although the individual will eventually constitute the unit of analysis, we first look at household income after tax (see Table 1) in order to later assign an income level to each individual based on household income allocated to household members according to two different equivalence scales. Income data is based on official income tax records and as such does not include income from sources like illegal employment and unpaid household work. In order to avoid potential distortions as a result of large losses on the stock market or negative income from self-employment, negative employment and/or capital income was set equal to zero before calculating total household income $\mathrm{s}^{5}$. Interest payments on mortgages or other loans are not included in our income definition, neither is any attempt made to account for an income equivalent for the value of owner-occupied housing or other differences in purchasing power due to housing costs.

\footnotetext{
${ }^{5}$ In 1997 17,742 working-age persons were members of households with negative capital income and 7,106 lived in households with negative labor income. Only $1.8 \%$ and $2.0 \%$ of those with negative capital income ended up with the classification as poor with the OECD equivalence scale and the square-root scale, respectively, in our analysis. (Equivalence scales will be discussed later in this section.) A much larger portion - approximately one-third — of those with negative labor income were classified as poor, but this group only accounted for $2.8 \%$ and $2.5 \%$ of the poor population with the OECD scale and square-root scale, respectively.
} 
Table 1. Overview of income components

\begin{tabular}{|c|c|}
\hline Market income & $\begin{array}{l}=\text { Employment income } \\
\text { - wages } \\
\text { - income from self-employment } \\
+ \text { Capital income, for example } \\
\text { - interest } \\
\text { - stock dividends } \\
\text { - sale of stocks }\end{array}$ \\
\hline Total income & $\begin{array}{l}=\text { Market income } \\
+ \text { Transfers, such as: } \\
\text { - welfare } \\
\text { - old-age pension } \\
\text { - unemployment benefits } \\
\text { - child allowance } \\
\text { - student grants }\end{array}$ \\
\hline Income after tax & $\begin{array}{l}=\text { Total income } \\
\text { - taxes and negative transfers }\end{array}$ \\
\hline
\end{tabular}

We make use of two difference equivalence scales to compare households of various sizes. As equivalence scales make assumptions about the extent of the economies of scale within households, poverty analysis can be highly sensitive to the choice of equivalence scale. Our first scale, the square-root scale, assigns each household member an equivalent income by dividing total household income (after tax) by the square root of the number of household members. The second scale, the OECD scale, applies different weights to adults and children: the first adult receives weight 1 , further adults the weight 0.7 and each child (under 16) the weight 0.5 . Total income is then divided by the total weight for household members and the amount thus obtained is allotted to each member. All household members therefore receive the same equivalent income level regardless of who actually earned the income. It is on the basis of these equivalent incomes that we calculate the poverty line at $50 \%$ of median equivalent income after tax in the (entire) population.

As the example in Table 2 illustrates, the square-root scale entails larger economies of scales within a household than the OECD scale. The two scales can therefore lead to different and even conflicting results with respect to the relative level of poverty among certain groups in society. A Norwegian study of the sensitivity of poverty results with the use of different equivalence scales in conjunction with a relative poverty line given at $50 \%$ of median income indicates that the level of poverty in the entire population is generally larger when an equivalence scale with larger economies of scale is used (Lund and Aaberge, 1999). More importantly however, 
certain demographic groups can be highly sensitive to the choice of equivalence scale depending in particular on the type of household composition prevalent in those groups. Use of two different equivalence scales will therefore be particularly useful in helping us establish which results are robust to such considerations.

Table 2. Comparison of scale rates for two alternative equivalence scales Household income necessary for different households if each member is to receive an equivalent income of NOK 100000.

\begin{tabular}{|c|c|c|c|c|}
\hline \multirow{2}{*}{$\begin{array}{l}\text { Household } \\
\text { composition }\end{array}$} & \multicolumn{2}{|c|}{ Square-root scale } & \multicolumn{2}{|c|}{ OECD scale } \\
\hline & weight & income (NOK) & weight & income (NOK) \\
\hline 1 adult & 1,00 & 100000 & 1,00 & 100000 \\
\hline 1 adult, 1 child & 1,41 & 141000 & 1,50 & 150000 \\
\hline 2 adults & 1,41 & 141000 & 1,70 & 170000 \\
\hline 2 adults, 1 child & 1,73 & 173000 & 2,20 & 220000 \\
\hline 2 adults, 2 children & 2,00 & 200000 & 2,70 & 270000 \\
\hline \multirow[t]{2}{*}{2 adults, 3 children } & 2,24 & 224000 & 3,20 & 320000 \\
\hline & \multicolumn{2}{|c|}{$\rightarrow$ larger economies of scale } & \multicolumn{2}{|c|}{$\rightarrow$ smaller economies of scale } \\
\hline
\end{tabular}

While use of data from the entire country makes the study of small immigrant groups possible, it also brings with it a complication that revolves around the increasingly large number of cohabitants in the Norwegian population. The above discussion about equivalence scales indicates the large part economies of scale can play in poverty analysis. Failure to correctly identify households' composition can therefore lead to biases in poverty results. While cohabitant households with children can be identified in official Norwegian register data, identification of cohabitant households without children is not possible. As a result, cohabitants without children are registered as two separate single households in the database we use here.

Åserud (2001) developed a method of predicting cohabitation in the Norwegian population in order to approximate the effect on the Norwegian income distribution in 1997 and that method was implemented here. It should be noted that correct identification of cohabitants was not necessary as long as the 'simulated' cohabitant households resembled the true ones sufficiently to create a similar income distribution. Åserud's study indicated that inclusion of cohabitant households should result in a decrease in inequality and poverty. The distribution created by our match-making methods did in fact result in the expected change in the Gini-coefficient and the Ginicoefficient with our 'simulated' cohabitants was, in fact, not significantly different than that obtained by Åserud (2001), who was able to identify actual cohabitants for the sample of the population used in his study. Our data also exhibited the expected 
reduction in poverty upon inclusion of cohabitant households (see Table 3$)^{67}$.

Table 3. Comparison of Gini coefficient and percentage of poor in entire population with and without cohabitants as households.

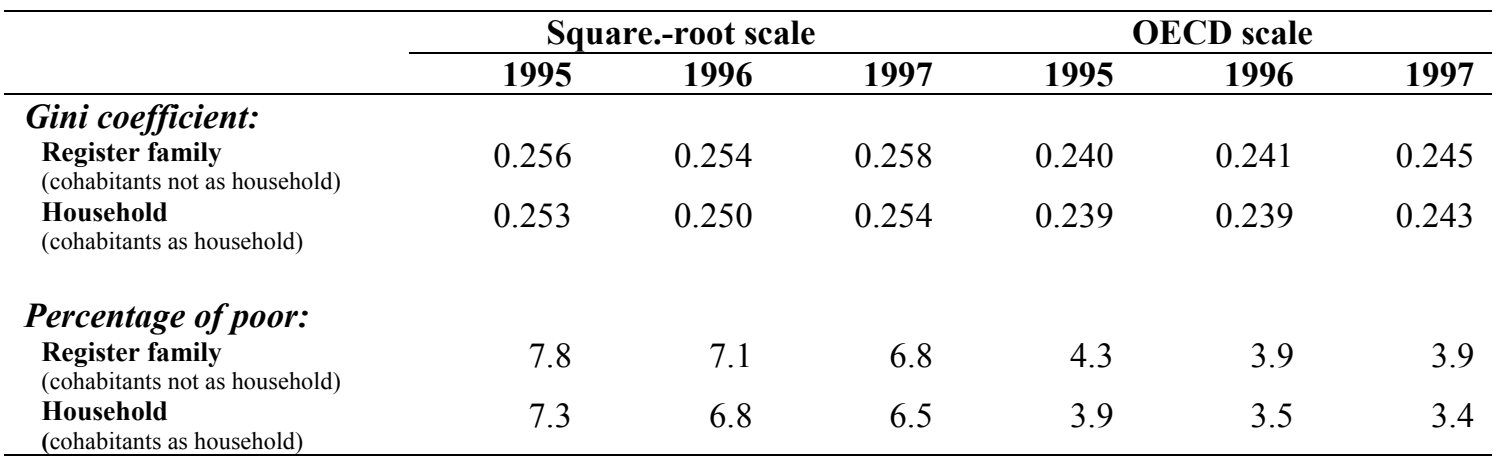

\section{A Brief Overview of Immigration and Poverty in Norway}

Immigration from non-Western countries is a relatively new phenomenon in Norway. Net immigration in Norway was, in fact, negative up until about the late1960s, and it was only after positive net immigration persisted for a number of years that any real restrictions on immigration were implemented in 1975. Due to similarities in language and culture as well as formal political agreements allowing for free movement - also for labor immigration - among the Nordic countries, large numbers of Nordic immigrants have been common for quite some time. Similarly, Norway's involvement in the European Economic Area (EEA) also allows for free movement into the country for EEA-citizens. After 1975, immigration from non-EEA countries has been restricted to three main kinds: specialist (skills-based) labor immigration, family reunification, and political asylum. At the same time, large-scale immigration from non-Western countries first started in the early 1970s. In fact, as Table 4 indicates, the number of non-Western and Eastern European immigrants surpassed Western immigrants only at the start of the 1990s. By the early 1990s, immigrants from Eastern Europe, Asia, Africa, Turkey and South and Central America accounted for roughly one-half of the immigrant population.

\footnotetext{
${ }^{6}$ Åserud (2001) used survey data on approximately 10,000 households from Statistics Norway to identify and then model the affinity for having a cohabitant with certain characteristics based, in particular, on level of education and age group. We used the estimated parameters from Åserud's model together with address information to predict and simulate cohabitation in the official data on the entire population. Single women and men with the same address who best fit together according to the affinities based on Åserud's estimates were then treated as cohabitants in our study.

${ }^{7}$ Unless otherwise stated tables and figures will be based on own calculations.
} 
Table 4. Composition of the immigrant population of Norway by ethnic origin, total numbers and percent of immigrant population

\begin{tabular}{|c|c|c|c|c|c|c|c|c|c|c|}
\hline & \multicolumn{2}{|c|}{ Nordic countries } & \multicolumn{2}{|c|}{$\begin{array}{l}\text { Western Europe } \\
\text { except Turkey }\end{array}$} & \multicolumn{2}{|c|}{ Eastern Europe } & \multicolumn{2}{|c|}{$\begin{array}{l}\text { North America, } \\
\text { Oceania }\end{array}$} & \multicolumn{2}{|c|}{$\begin{array}{l}\text { Asia, Africa, South } \\
\text { and Central }\end{array}$} \\
\hline & number & percent* & number & percent* & number & percent* & number & percent* & number & percent* \\
\hline 1970 & 26548 & 44.8 & 15190 & 25.7 & 5806 & 9.8 & 8103 & 13.7 & 3549 & 6.0 \\
\hline 1980 & 31210 & 32.8 & 22686 & 23.8 & 7114 & 7.5 & 11810 & 12.4 & 22382 & 23.5 \\
\hline 1986 & 35766 & 29.0 & 28503 & 23.1 & 8868 & 7.2 & 11332 & 9.2 & 38879 & 31.5 \\
\hline 1987 & 37880 & 28.9 & 28797 & 22.0 & 9374 & 7.1 & 11320 & 8.6 & 43771 & 33.4 \\
\hline 1988 & 39509 & 27.0 & 29420 & 20.1 & 10639 & 7.3 & 11350 & 7.8 & 55379 & 37.9 \\
\hline 1989 & 40037 & 25.0 & 29972 & 18.7 & 11878 & 7.4 & 11292 & 7.0 & 67114 & 41.9 \\
\hline 1990 & 38089 & 22.6 & 29107 & 17.3 & 13551 & 8.1 & 10769 & 6.4 & 76782 & 45.6 \\
\hline 1995 & 40608 & 18.9 & 28853 & 13.4 & 30276 & 14.1 & 10211 & 4.7 & 105100 & 48.9 \\
\hline 1996 & 41643 & 18.6 & 29188 & 13.0 & 33200 & 14.8 & 10037 & 4.5 & 109729 & 49.0 \\
\hline 1997 & 43696 & 18.8 & 29491 & 12.7 & 34486 & 14.9 & 9879 & 4.3 & 114640 & 49.4 \\
\hline
\end{tabular}

The extent to which immigrants have access to the same transfers and government-funded programs as natives varies according to the specific benefit or program. Child allowance is given to all families with children residing in Norway, regardless of their nationality and regardless of their earnings. Unemployment insurance benefits are granted on the basis of a person's labor market history, and the same rules and rights are in place regardless of nationality. There are some slight differences with respect to disability and old-age pensions, which in part depend upon the number of years in the country ${ }^{8}$. Access to labor market programs through the employment office is generally along the same lines as for natives, and some programs are specifically intended for immigrants. All adult immigrants have access to free language instruction up to 850 classroom hours ${ }^{9}$. Refugees have the same access to educational grants and loans as natives. Although access to such funding is more limited for other immigrants, it is far from impossible. If, for example, an immigrant has worked full-time for a year before the commencement of studies, then he or she is eligible for the same educational grants and loans as natives.

Table 5 uses cross-sectional data to illustrate the large differences in the percentages of poor in groups of different ethnic origin in the period 1995-1997 ${ }^{10}$.

\footnotetext{
${ }^{8}$ Disability and old-age pensions generally consist of two parts, a basic pension and a supplementary pension. Immigrants and natives are treated essentially the same with regards to the supplementary pension, the part of the pension which depends on the person's earnings history. The basic (minimum) pension, however, depends on the length of the 'insured period', which for immigrants is the length of time in the country. (For natives it is the length of time since age 16.) A 40 year 'insured period' is needed to get the full basic pension.

${ }^{9} \mathrm{Up}$ to 3000 hours for immigrants with no formal education.

${ }^{10}$ Table A.1 in the Appendix provides information on the percentage of working age persons with even lower income-less than $25 \%$ of median annual (equivalent) income after tax. While income that low is
} 
Poverty seems to be a very prevalent phenomenon in the immigrant community in Norway, particularly among non-Western immigrants, but the estimates presented in Table 5 fail to take into account differences in age, education and type of household in the various ethnic groups. In addition, those figures are an average over various immigrant cohort groups. The high percentages may therefore be due to a large prevalence of poverty among immigrants who have just arrived recently while the incidence of poverty among more established immigrants may not differ greatly from that of the native population.

Table 5. Percentage of poor in working age population* in Norway by ethnic origin 1995-1997

\begin{tabular}{lrrrrrr}
\hline & \multicolumn{3}{c}{ Square-root scale } & \multicolumn{3}{c}{ OECD scale } \\
& $\mathbf{1 9 9 5}$ & $\mathbf{1 9 9 6}$ & $\mathbf{1 9 9 7}$ & $\mathbf{1 9 9 5}$ & $\mathbf{1 9 9 6}$ & $\mathbf{1 9 9 7}$ \\
\hline All & 4.5 & 4.3 & 4.0 & 3.2 & 3.2 & 3.0 \\
\hline By ethnic origin: & & & & & & \\
$\quad$ Norway & 3.7 & 3.4 & 3.3 & 2.5 & 2.3 & 2.2 \\
Nordic country & 7.1 & 9.5 & 7.6 & 5.8 & 8.1 & 6.5 \\
Western country** & 14.4 & 17.2 & 14.1 & 13.1 & 16.2 & 13.2 \\
Eastern Europe & 23.3 & 20.2 & 17.3 & 22.4 & 19.8 & 17.0 \\
Asia (incl. Turkey) & 22.3 & 20.2 & 18.8 & 23.5 & 22.3 & 20.9 \\
Africa & 25.2 & 23.1 & 20.3 & 23.2 & 22.9 & 20.4 \\
South and Central American & 16.4 & 16.8 & 13.9 & 13.8 & 14.3 & 12.4 \\
\hline
\end{tabular}

*Age 16-68, not in education

**Western Europe (non-Nordic), North America, Australia and New Zealand

Similarly, the picture presented in Figure 1 seems to suggest that just such a negative relationship between the percentage of poor immigrants and the length of time since their migration may exist, but, as already mentioned, it too may be very misleading if that negative relationship is largely due to changes in the demographic composition of the immigrant population over the course of the last few decades.

extremely rare for natives, large percentages of immigrants do fall into this category for an annual measure of poverty, i.e. based on income from one year alone. However, Table A.2, which is based on income from a three-year period, indicates that persistent income at such a very low level is also very rare among immigrants. (See subsection 4.2 for further discussion of chronic poverty, i.e. poverty based on income from several years.) 
Figure 1. Percentage poor in working age population* in Norway in 1996 by ethnic origin and number of years since migration.

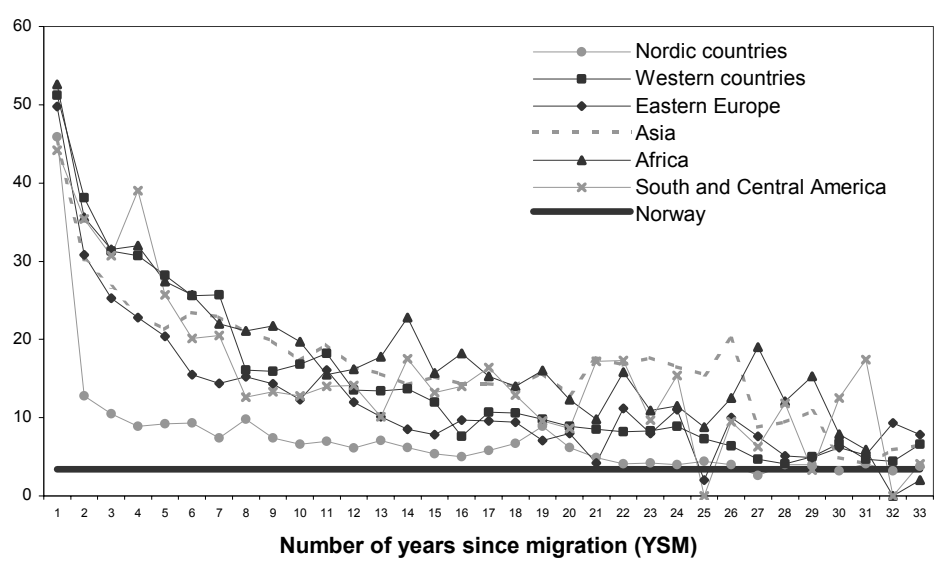

*Age 16-68, not in education

The logistic regressions based on cross-sectional data for 1997 presented in the next section can be viewed as an attempt to find some answers to the effect of what we shall very broadly refer to as integration or assimilation. Integration is, of course, a very diffuse and complicated concept which is difficult for the researcher to observe and even more difficult to measure, but it is reasonable to assume, as we do here, that the length of time the immigrant has spent in his or her new country provides a proxy for at least potential integration. Alternatively, the number of years since migration could be interpreted as experience and potential for investment in human capital in the new country and society, be it with respect to language, culture, the educational system, the labor market or the social security system.

\section{Prevalence of Poverty among Immigrants}

\subsection{Poverty Defined in Terms of Annual Income}

The relationship between classification as poor and a number of person-related characteristics was modeled with the aid of logistic regressions. Due to the presumption of a very large degree of heterogeneity among immigrants groups of different ethnic origin, separate regressions were run for each of the groups. This allowed for the variables' effects to vary greatly in the different ethnic groups on the one hand, but also resulted in a smaller number of observations and less accurate estimates for some of the groups on the other hand. Model parameter estimates are presented in Tables A.3 and A.4 in the Appendix for both the square-root and OECD scales and some basic descriptive statistics on age and YSM are provided in Table A.5.

The number of years since migration (YSM) does indeed have a significantly 
negative effect on the probability of being poor, but the extent of the effect varies substantially across the different ethnic groups. Figure 2 shows the relationship between YSM and the probability of being poor based on the regression coefficients presented in Table A.3 and A.4 in the Appendix for married men without children at age 40 , the average age of working age immigrants in Norway ${ }^{11}$. We present diagrams for four different levels of education in order to simultaneously examine the effect of education on the probability of being poor in the various ethnic groups. While the expected differences in poverty results for the two different equivalence scales as described in Section 2 suggest that the estimated effect of YSM may have a different magnitude for the different scales, inspection of the coefficient estimates show that at least the sign of the effect is robust with respect to the choice of equivalence scale. In addition, the diagrams in Figure 2 suggest that the magnitude of the effect of YSM as well as the relative differences between the ethnic groups with respect to education level are also very similar for the two equivalence scales.

\section{Figure 2. The probability of poverty by ethnic origin and level of education}

Square-Root Scale

middle school or lower

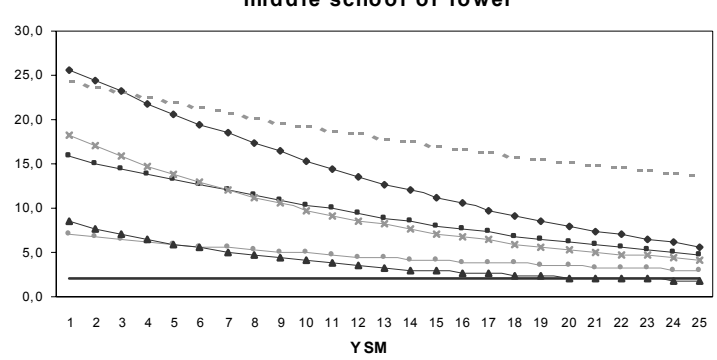

high school

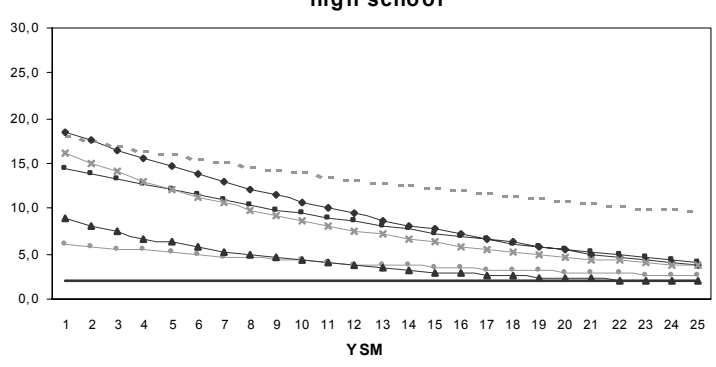

OECD Scale

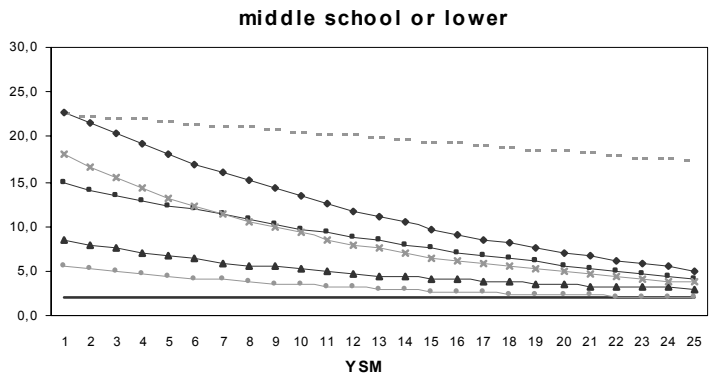

high school

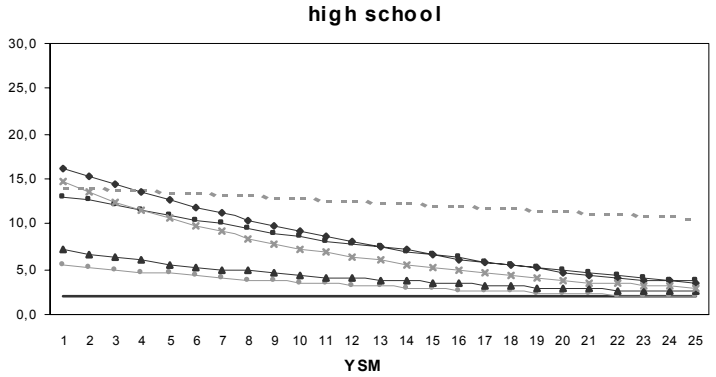

${ }^{11}$ See Figure A.1 in the Appendix for the probability of poverty relative to age. 

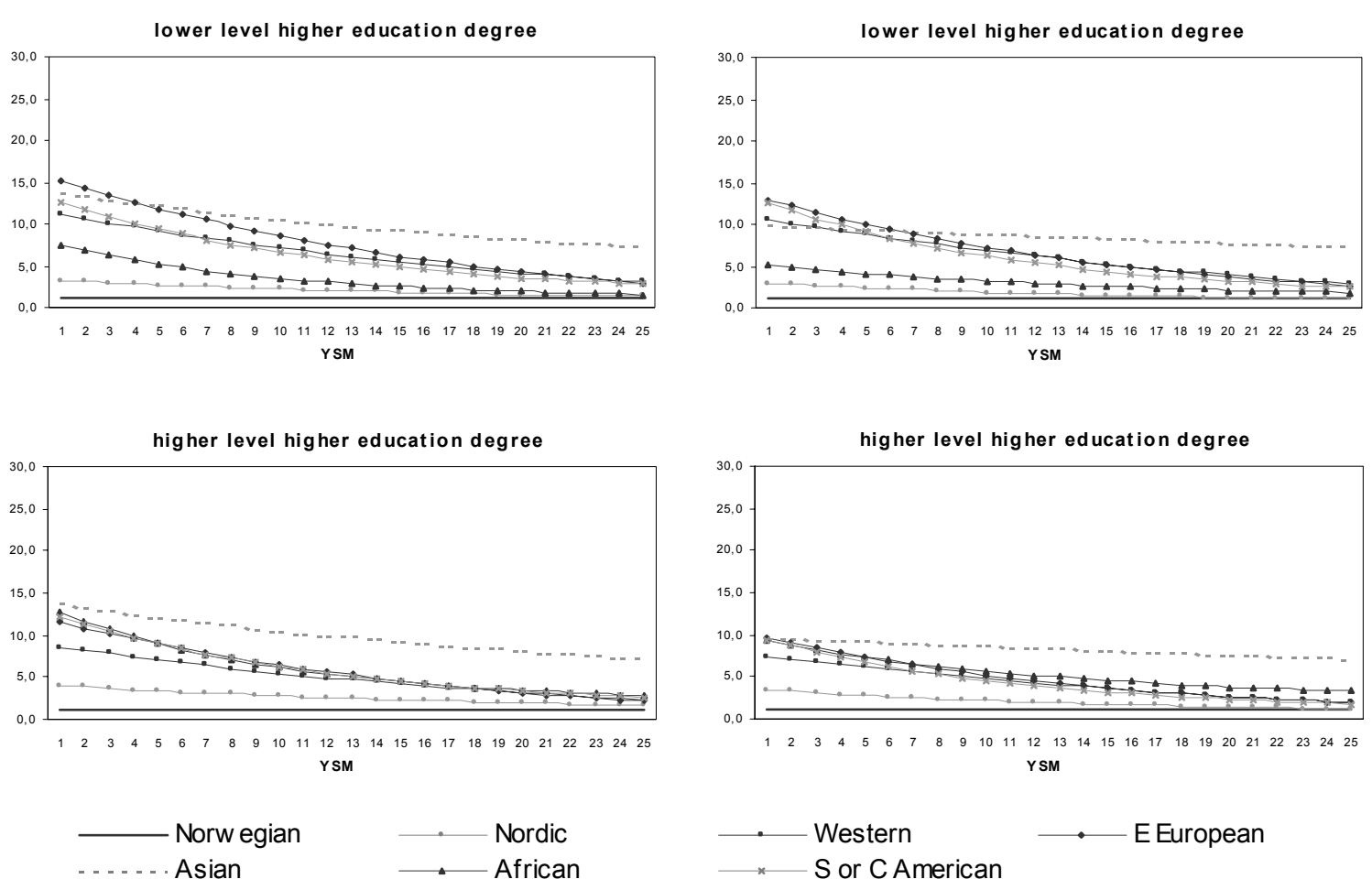

The predicted probabilities are calculated with the following variables held constant: age 40 (average age of working age immigrants in Norway), couple without children, male.

The diagrams in Figure 2 indicate that immigrant groups from Nordic countries, non-Nordic western countries, Africa, South and Central America and Eastern Europe all exhibit a strongly downward sloping relationship between YSM and the probability for being poor with a large degree of convergence towards the poverty level for natives. The curves cannot be said to converge entirely to the level of natives, except perhaps in the case of Nordic immigrants. Asian immigrants stand out as the group for which YSM has relatively little effect on the probability of being poor. African immigrants generally have a low predicted probability of being poor, but in light of that group's small size and the large standard deviations associated with the estimates for that group (see Table A.3 and A.4 in the Appendix), caution should be exercised in interpreting those results. Nordic immigrants are most similar to their native Norwegian counterparts shortly after arrival and their probability of being poor converges relatively quickly to a level similar to that of the native population. In light of the large degree of similarity in language, human capital and culture among the Nordic countries, one would expect that such immigrants face very little integration or assimilation difficulties and, hence, that just such a picture would emerge. This leaves the seemingly lack of a strong effect of YSM among Asian immigrants as the anomaly in this context, a topic which will be considered in greater detail in light of the general 
discussion and interpretation of results in the following discussion section.

Finally, it is also interesting to note that the differences between the groups in terms of the (starting) level of poverty probability seem to be smaller for higher education levels and that the groups converge more quickly to a common level for immigrants (excluding Asian immigrants) for higher education levels than for the lower ones. In particular, immigrants from different ethnic groups with a very high level of education (second level higher education degree) exhibit only small differences in the probability of being poor, while there is a large degree of dispersion in the probability of being poor for immigrants of different ethnic origin with a low level of education. This suggests that education leads to a certain degree of similarity between groups from the onset or very early on, that is, before or shortly after they arrive in Norway.

\subsection{Poverty Defined in Terms of Three-Year Income}

In a previous study of poverty in Norway, Aaberge et al. (1999) pointed out that annual income might not provide the best method of measuring (income) poverty. Annual results fail to consider the issues of transitions into and out of poverty as well as poverty duration. If, for example, many of the persons classified as poor based on annual income experience only temporary stints of poverty, then the annual measure may exaggerate poverty results both in extent and severity. Within this context, persistent low-income over several years constitutes a far greater threat to welfare than short-term income fluctuations that may lead to a classification as poor in one particular year.

The same income definition as above is used in this section, but the time period is extended from one to three years: in other words, individuals are considered chronically poor if their equivalent income after tax for the entire three-year period 1995-1997 lies below $50 \%$ of the median for that period. As with the annual results presented above, the poverty line was first constructed based on the population of all persons residing in Norway during the relevant period, but the population used in later regressions will be that of working-age persons not in education.

Table 6 and Table 7 indicate that the percentage of chronically poor as well as the effect of the move from annual income to three-year income varies across ethnic groups. Also in this case the native Norwegian population seems to fare best: very few natives are chronically poor and almost half of the poor in the native population in any 
given year are not considered chronically poor when income from several years is used to define the poverty line. A large portion of annual poverty in the native population can, thus, be attributed to income fluctuations that may not have a highly detrimental effect on welfare in the long run. Immigrants tend to have a higher proportion of chronically poor in their ranks than natives and fewer of the immigrants registered as poor with an annual measure in a given year escape classification as chronically poor.

Table 6. Percentage of chronically poor in working age population* in Norway by ethnic origin

\begin{tabular}{lcc}
\hline & Square-Root Scale & OECD Scale \\
\hline Norway & 2,8 & 1,8 \\
Nordic country & 2.4 & 1.3 \\
Western country** & 3.9 & 2.8 \\
Eastern Europe & 7.5 & 6.3 \\
Asia (incl. Turkey) & 15.2 & 13.8 \\
Africa & 15.9 & 14.8 \\
South and Central American & 16.6 & 12.8 \\
\hline
\end{tabular}

*Age 16-68, not in education

**Western Europe (non-Nordic), North America, Australia and New Zealand

Table 7. Percentage of persons classified as poor in a given year who are not classified as chronically poor based on total income after tax for the entire threeyear period.

\begin{tabular}{lcccccc}
\hline & \multicolumn{2}{c}{ Square-Root Scale } & \multicolumn{3}{c}{ OECD Scale } \\
& $\mathbf{1 9 9 5}$ & $\mathbf{1 9 9 6}$ & $\mathbf{1 9 9 7}$ & $\mathbf{1 9 9 5}$ & $\mathbf{1 9 9 6}$ & $\mathbf{1 9 9 7}$ \\
\hline Norway & 48.4 & 40.3 & 46.9 & 51.6 & 42.7 & 47.9 \\
Nordic country & 49.3 & 30.8 & 33.6 & 50.6 & 29.7 & 31.4 \\
Western country** & 36.1 & 21.6 & 27.0 & 34.8 & 21.1 & 25.8 \\
Eastern Europe & 42.8 & 28.5 & 29.7 & 45.5 & 34.1 & 33.7 \\
Asia (incl. Turkey) & 38.6 & 25.4 & 29.9 & 45.6 & 37.3 & 40.1 \\
Africa & 42.8 & 28.6 & 28.5 & 45.3 & 34.7 & 35.6 \\
South and Central American & 39.6 & 31.7 & 32.4 & 38.3 & 28.8 & 32.1 \\
\hline
\end{tabular}

*Age 16-68, not in education

**Western Europe (non-Nordic), North America, Australia and New Zealand

Figure 3, which is based on the estimated coefficients presented in Table A.6 and A.7 in the Appendix, indicates that a negative relationship between YSM and the probability of chronic poverty also exists, although the slopes of the curves appear to be flatter than with an annual measure of poverty. In this respect it should however be noted that, due to the definition of chronic poverty used here, the population consists of only those immigrants who were in the country all three years 1995-1997. Hence, immigrants with YSM less than three could not be included in this analysis. This may, in part, account for the lower starting points for the curves in Figure 3 compared with those in Figure 2. Nonetheless, that alone cannot account for the differences between 
the figures: the effect of income fluctuations and the differences between the various ethnic groups in that regard must also play a part.

Comparison of Figure 2 and Figure 3 also shows that the move from an annual measure of poverty to a chronic one influences results for immigrants with lower education levels the most. That suggests that immigrants with lower education levels may often experience short-term stints of poverty, but nonetheless escape poverty when a longer accounting period is used as the basis for defining poverty. The curves for immigrants with higher education levels exhibit such an effect to a far lesser extent. The relative importance of the effect as we move from an annual to a chronic measure also varies greatly across ethnic groups.

Figure 3. The probability of chronic poverty by ethnic origin and level of education

Square-Root Scale

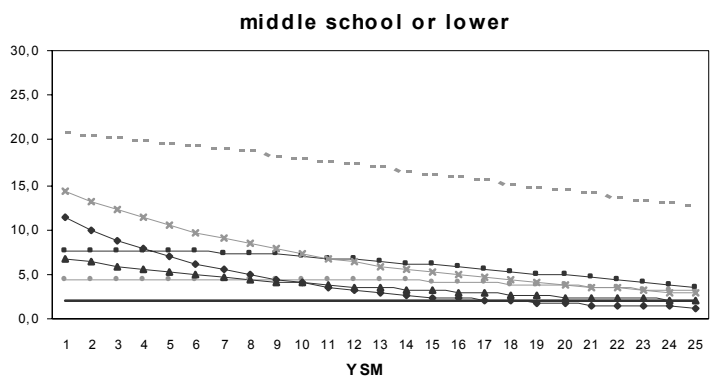

high school

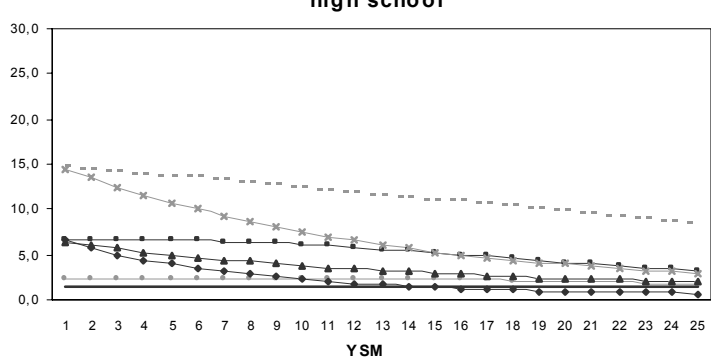

YSM

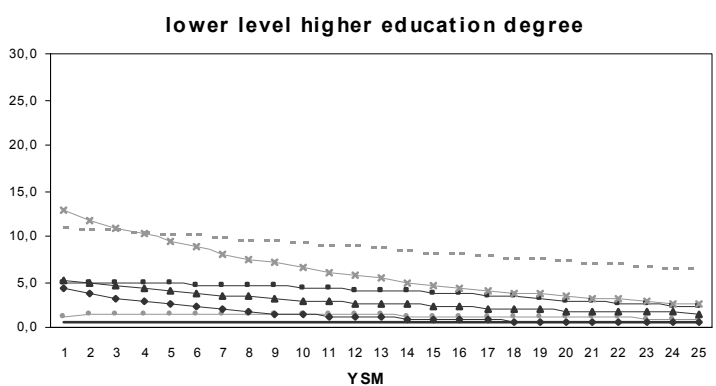

OECD Scale

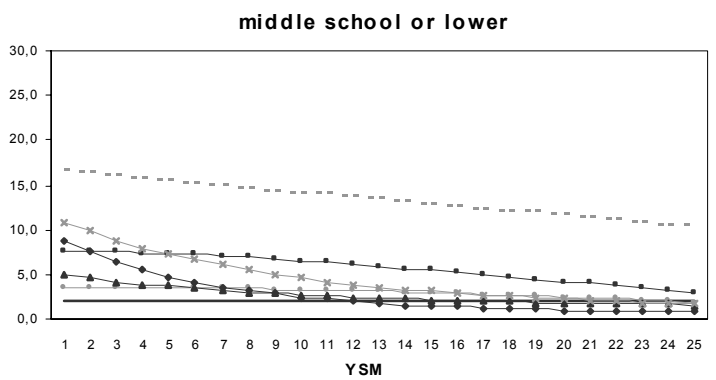

high school

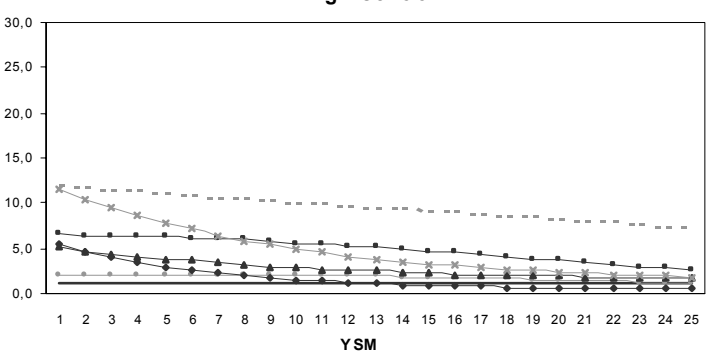

YSM

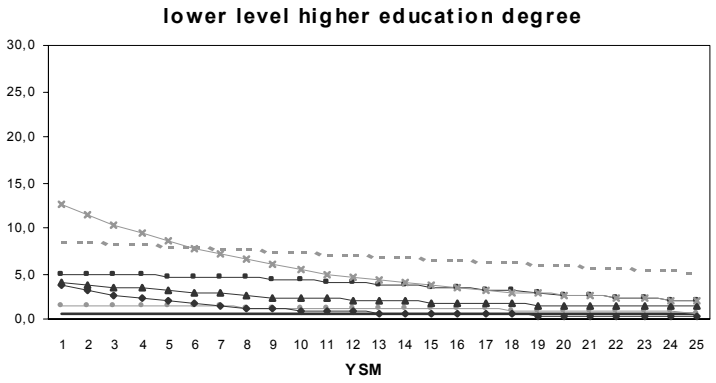



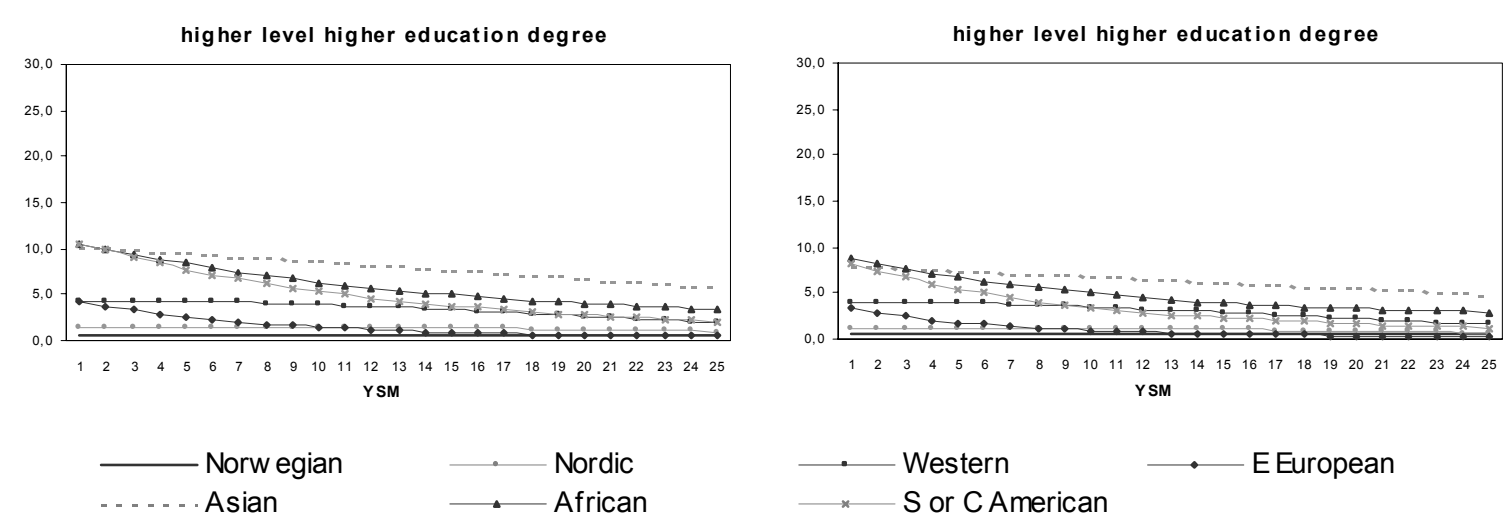

The predicted probabilities are calculated with the following variables held constant: age 40 (average age of working age immigrants in Norway), couple without children, male.

In order to help establish just what sort of income factors are important in raising some households above the poverty line, Figure 4 compares the income composition of the chronic poor with that of those individuals just above the poverty line (i.e. with an income level between 50 and 60 percent of median equivalent income after tax over a three year period) for natives and immigrants by ethnic origin. The different ethnic groups vary greatly in their average income composition, but, in general, labor income is the largest income source. Transfers do, however, make up a very large part of total average income, and, in the case of non-Western immigrant groups, account for nearly as much as labor income. That does lend support to our claim that focusing on wage assimilation may not provide the whole story with regards to the welfare assimilation of immigrants, i.e. the extent to which immigrants are able to avoid very low levels of income in a manner similar to natives. Labor income and the type of assimilation that occurs with respect to wages has an undeniably large effect, but Figure 4 demonstrates that it may not be the only relevant factor. 
Figure 4. Income Composition over Three Years of the Chronic Poor Compared to Individuals Just Over the Chronic Poverty Line*

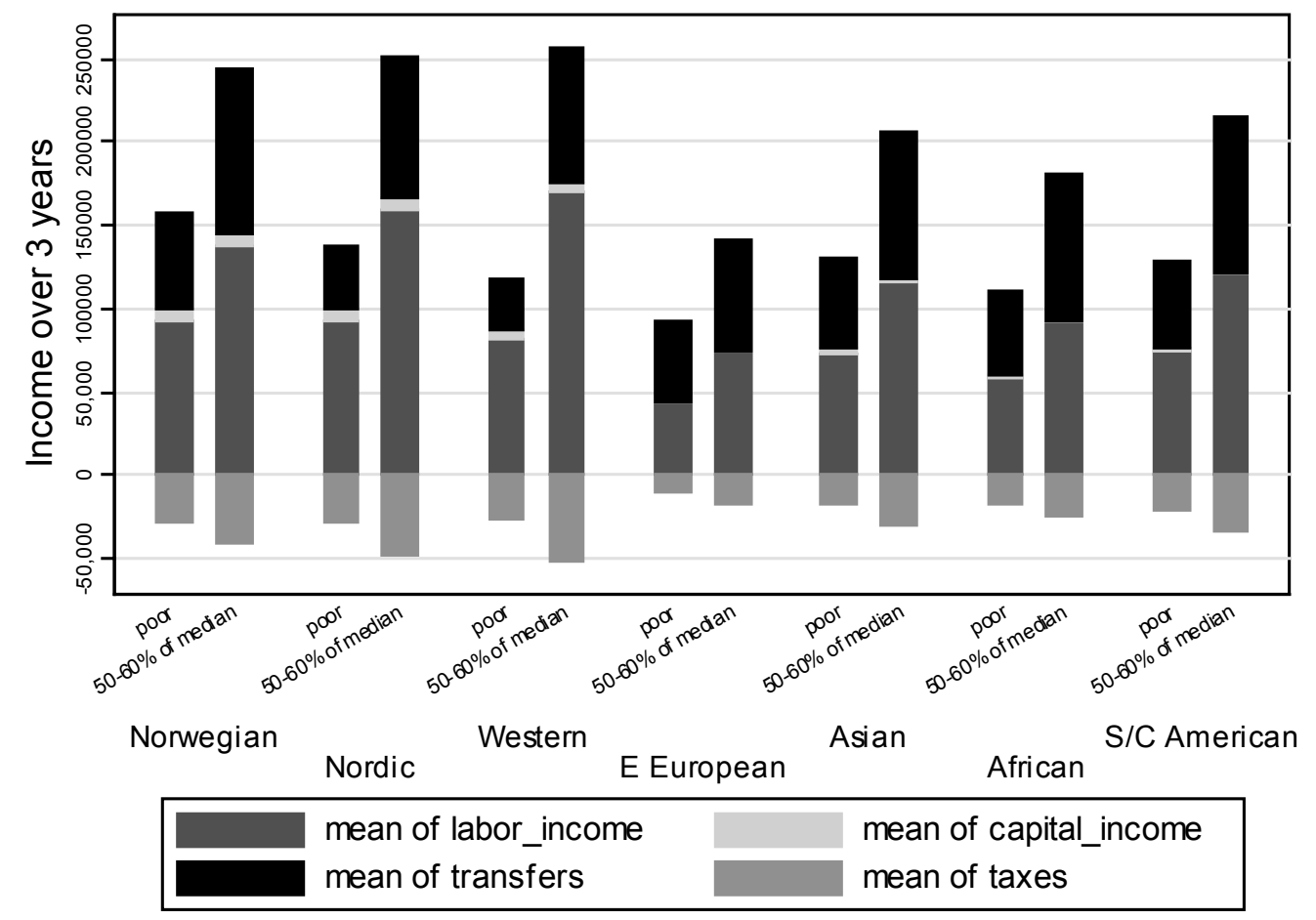

*Individuals with equivalent income after tax between 50 and 60 percent of the median

\section{Discussion}

The results in the preceding section suggest three main questions: why might a negative relationship between YSM (years since migration) and the probability of poverty exist, why might the extent of that effect vary across ethnic groups and, finally, what might our findings fail to take into account? In exploring these questions we would like to also keep in mind the seemingly weak YSM effect for Asian immigrants.

Some of the possible reasons for the observed negative relationship between YSM and the probability of being poor will surely lie with the labor market participation of immigrants. As mentioned in the introduction, studies on the assimilation of immigrant wages relative to the native population suggest that some assimilation does take place, that is, that immigrants' wages do, after a sufficiently long period in the country, increase relative to the wages of natives. Such growth in wages relative to the native population may raise some immigrants (and their households) out of poverty after a certain amount of time. In addition, the labor market 
participation of immigrants may increase over time either through lower unemployment or by means of more immigrants actually pursuing employment. While the relationship from improved labor market income, either through rising relative wages or increased labor market participation, and lower incidence of poverty is more or less a direct one, it is nonetheless difficult to ascertain the actual mechanisms leading to higher relative wages and/or labor market participation. Borjas (1994) points out the importance language acquisition has been given in the literature attempting to explain some sort of difference in human capital accumulation between immigrants and natives as the mechanism underlying wage assimilation. Borjas also notes that while many of these studies indicate very large returns to language capital for immigrants, they often fail to take into account the potential selection bias in acquiring language proficiency in the first place, that is, that high-wage workers may simply have or quickly acquire better language skills, not vice versa.

However, as emphasized in the introduction, human capital accumulation and labor market performance are far from the only aspects that enter into poverty analysis. The tax and social security system can also have a direct influence on immigrants' income and, hence, the probability of being poor via tax deductions, universal transfers and means-tested programs as well as indirectly by means of labor market and educational programs with long-term returns. Moreover, the tax and social security system of any country may be difficult even for natives to understand, never mind immigrants who face difficulties with the language and culture. After some time in the country, immigrants may be better able to understand and benefit from the various programs available. In addition, even if immigrants have problems on the labor market, participation in temporary, part-time or low-paying jobs may nonetheless help them obtain rights to such benefits as unemployment and disability insurance as well as loans and stipends for education or other means of accumulating human capital; at the same time, once immigrants do manage to obtain steady employment with wages that raise them above the poverty line, the rights they have earned through such employment can prevent them from falling back into poverty in the event of unemployment, sickness or simply old-age.

The effects of the two aforementioned aspects-labor market participation and eligibility and participation in the tax and social security system-may also differ across the various immigrant groups. As already indicated with respect to Nordic immigrants, certain groups will be expected to have little adjustment problems from 
the start. Hence, their labor market performance would be expected to be better from the onset implying that their starting probability of being poor would be lower and the effect from addition years in the country less. Other groups may start out at a very high level due to initial difficulties that are easily overcome over time. That scenario fits in well with the picture for Eastern European immigrants, who start off at a very high probability of being poor, but experience a rapid decrease in the probability of poverty over time. The formal and cultural ties to these countries were for obvious historical reasons less developed than the ties with Western Europe and, hence, one would expect that that group would experience initial difficulties. At the same time, that group certainly shares in what could be considered a common European background. Hence, they would be expected to have less trouble in overcoming initial difficulties than other groups with far less in common culturally and could, therefore, be more successful in raising their income above the poverty line.

In addition, immigrant groups may differ in the networks and ties they form within their respective ethnic communities. Such networks could conceivably have both a negative and a positive effect on the probability of being poor. On the one hand, strong ethnic communities may assist new arrivals in understanding how to function in their new environment. Ethnic community networks may provide channels by which to transfer information on available jobs and opportunities or, in the case of very large groups, the ethnic community may itself even constitute a source of employment for compatriots in ethnic-owned businesses. Within the American context, Borjas and Hilton (1996) show that immigrants' participation in welfare programs often exhibit patterns along ethnic lines and suggest that ethnic communities may transmit knowledge of certain types of benefits to new arrivals. On the other hand, the presence of strong ethnic communities may hinder language acquisition or the incentive to interact with the larger native community.

All of the above-mentioned factors-labor market performance, social security benefits and the existence and activity of ethnic networks - can have contributed to the relatively flat curve for Asian immigrants in Figure 2. Immigrants from Pakistan and Vietnam constitute two of the largest immigrants groups in Norway and are, in addition, two of the non-Western groups that have been in the country in substantial numbers the longest. As such, these groups would be good candidates for strong ethnic community networks, with all of the potential effects described above. Several different scenarios are possible: new arrivals from Asia may by themselves have a 
much higher probability of being poor, but help from the ethnic community prevents them from becoming poor early on. This could also be the case if large numbers of new arrivals come as family members and therefore join households made up of immigrants with longer 'experience' in Norway and a lower probability of being poor. That suggests that the 'true' curve for Asian immigrants might start at a much higher level and then have a steeper slope than we can observe. The effect of YSM might, in other words, exist as immigrants become more self-sufficient and less reliant on aid from their ethnic community, but that might not be observable in our data. Strong ties within such ethnic communities might, however, also lead to a situation in which the immigrants largely stay within their own communities and do not gain the skills and knowledge they need to improve their income and escape from poverty.

Another possible scenario also brings up a major drawback or possible shortcoming of our analysis. The cross-sectional nature of our data may mean that the curves presented in Figures 1 and 2 do not represent assimilation effects at all or only to a far lesser degree than suggested by the graphs. They might instead reflect differences in cohort groups over time. In other words, the immigrants who arrived 20 years ago may have in some important ways been better suited to succeed in their new environment and therefore even at the time of their arrival had a lower probability of poverty. Such a possible deterioration of cohort quality may also have taken place to a lesser or greater extent in different ethnic groups, thus explaining the differences in the slopes of the curves in Figures 1 and 2. Differences in the economic climate at the time of arrival might also have contributed to differences in the probability of poverty for different cohort groups.

In a similar manner, it could be argued that non-random selection effects may also have an impact on our results. The low probability of poverty among what is essentially earlier immigrant cohorts may reflect a situation in which only successful immigrants remained in Norway, while unsuccessful immigrants - those that were unable to raise their standard of living above a certain level such as the poverty linereturned to their native countries or went elsewhere. In other words, the immigrants from earlier cohort groups that still turn up in our data may represent a non-random positive selection of the immigrants that entered the country at earlier dates versus more recently.

A Norwegian study of the migration behavior of immigrants to Norway (Tysse and Keilman, 1998) suggests that the potential for such self-selection is, however, 
small among non-Western immigrants ${ }^{12}$. Table A.8 in the Appendix provides results from Tysse and Keilman (1998) with regards to the migration behavior as of 1996 among 1986-1990-immigrant cohorts, a group highly relevant with respect to our data. Strikingly, the percentage of non-Western immigrants remaining in the country is largely unaffected by their employment status: $96 \%$ of employed immigrants from Eastern Europe as well as Asia, Africa and South and Central America remain in the country 5-10 years after initial immigration while over $97 \%$ of the unemployed immigrants from those same regions are also still residing in the country. ${ }^{13}$

While the results we have presented here do for the most part suggest a negative relationship between the length of time in Norway and immigrants' probability of being poor, they also suggest a number of questions for further research. With time we will be able to track the same immigrants as a panel with a longer time series in order to attempt to separate the cohort effect from the true effect of increased assimilation. In addition, the actual mechanisms leading to the negative relationship need to be uncovered by looking more closely at how such issues as labor market performance, human capital accumulation, and transfers relate to immigrants' probability of poverty.

\footnotetext{
${ }^{12}$ The potential for such self-selection appears greatest for Western immigrants, in other words, those immigrants that have the least problems from the start and, hence, are only of limited interest for this study. See Table A.8 in the Appendix.

${ }^{13}$ Migration out of the country occurs mostly for the categories "outside of the labor force" and "unknown". According to Tysse and Keilman (1998), the former group largely consists of students, who we have already excluded from our analysis, while the latter group is to a large extent made up of immigrants with such a short duration of stay in Norway that they are never registered with any sort of employment status. The authors suggest that that asylum seekers refused asylum are a major group in this category.
} 


\section{Appendix}

\section{Figure A.1. The probability of poverty by age and ethnic origin}

\section{Square-Root Scale}

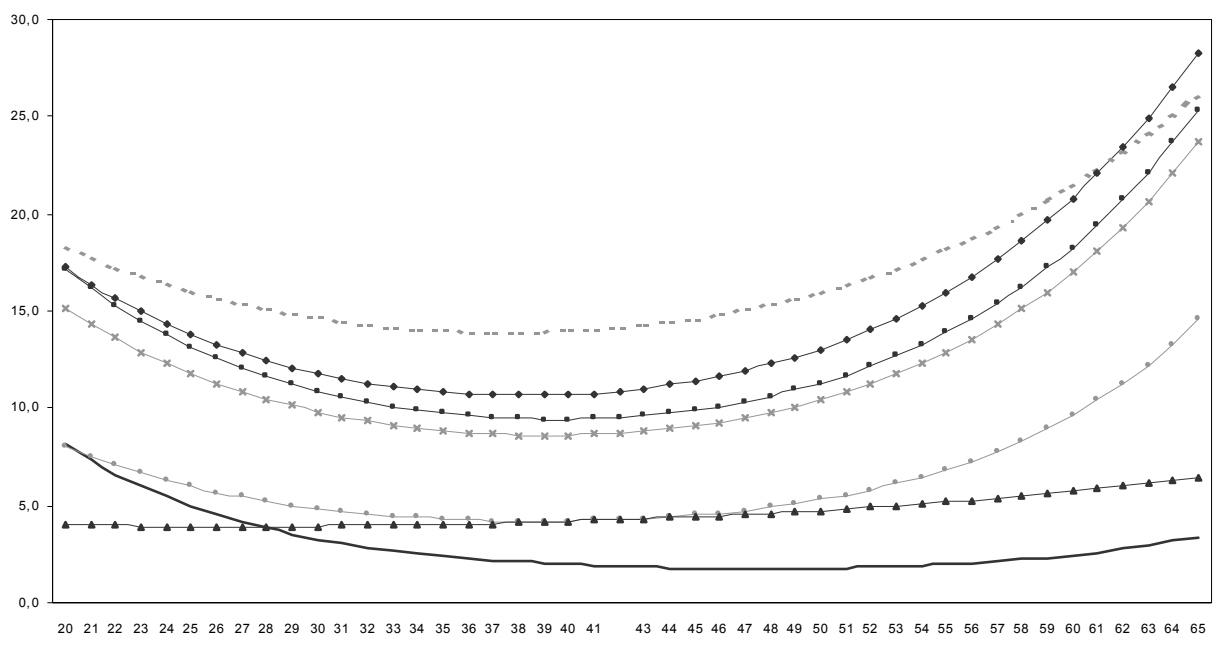

AGE

\section{OECD Scale}

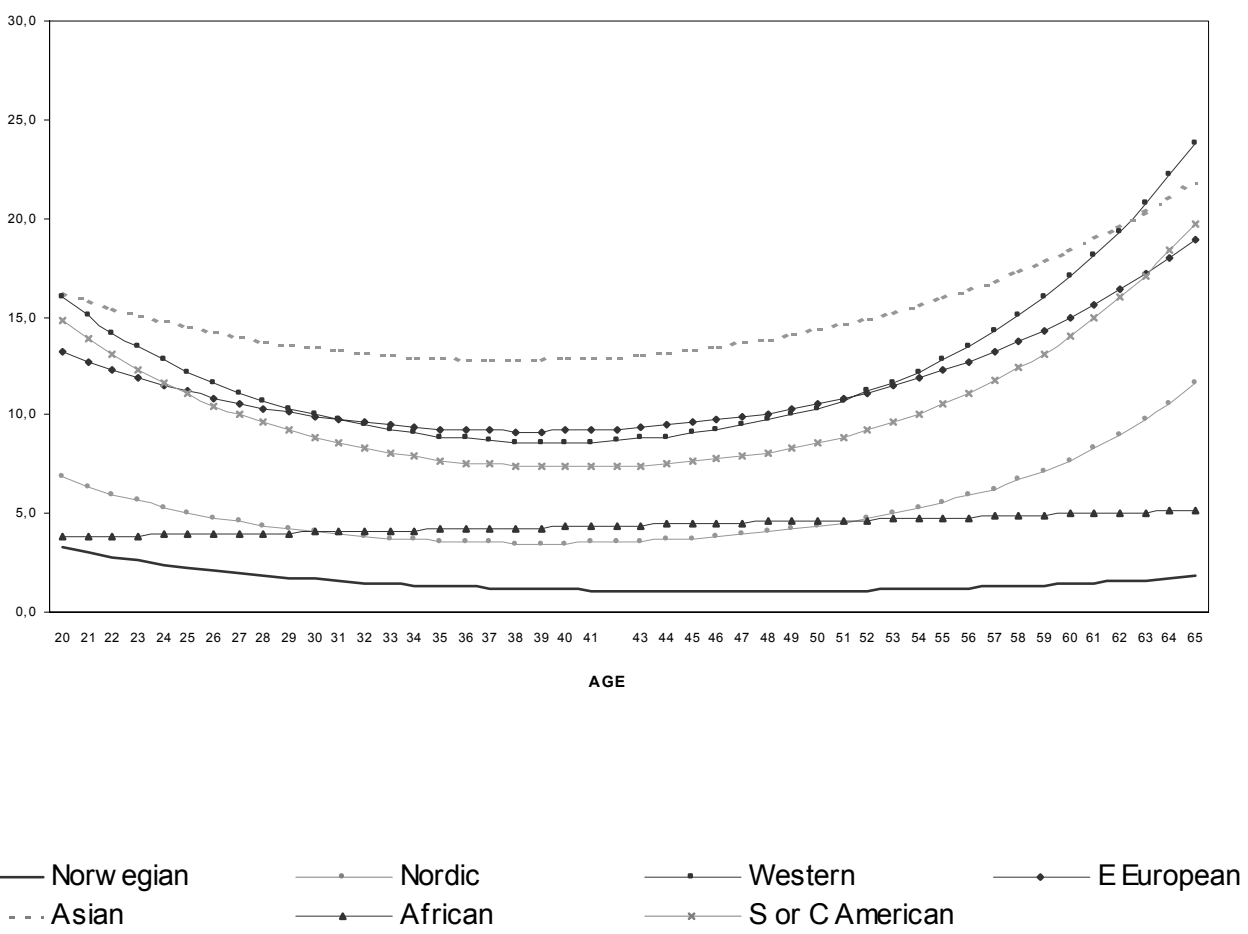

The predicted probabilities are calculated with the following variables held constant: YSM=10 for immigrants, couple without children, male, high school education. 
Table A.1. Percentage of working age population* with income under 25 percent of annual median equivalent income after tax in Norway by ethnic origin. 1995-1997.

\begin{tabular}{lrrrrrr}
\hline & \multicolumn{3}{c}{ Square-root scale } & \multicolumn{3}{c}{ OECD scale } \\
& $\mathbf{1 9 9 5}$ & $\mathbf{1 9 9 6}$ & $\mathbf{1 9 9 7}$ & $\mathbf{1 9 9 5}$ & $\mathbf{1 9 9 6}$ & $\mathbf{1 9 9 7}$ \\
\hline All & 1.2 & 1.1 & 1.0 & 1.0 & 0.9 & 0.9 \\
\hline By ethnic origin: & & & & & & \\
Norway & 0.8 & 0.7 & 0.7 & 0.7 & 0.6 & 0.6 \\
Nordic country & 2.8 & 3.8 & 3.2 & 2.6 & 3.5 & 2.9 \\
Western country** & 9.0 & 11.4 & 9.3 & 8.6 & 11.1 & 9.0 \\
Eastern Europe & 8.9 & 6.8 & 5.3 & 8.6 & 6.4 & 5.0 \\
Asia (incl. Turkey) & 7.8 & 7.0 & 6.2 & 7.4 & 6.8 & 6.0 \\
Africa & 10.4 & 9.7 & 8.0 & 9.6 & 9.1 & 7.4 \\
South and Central American & 6.8 & 6.8 & 5.6 & 6.2 & 6.4 & 5.1 \\
\hline
\end{tabular}

*Age 16-68, not in education

**Western Europe (non-Nordic), North America, Australia and New Zealand

Table A.2. Percentage of working age population* in Norway under 25 percent of median three-year equivalent income after tax by ethnic origin. 1995-1997.

\begin{tabular}{lcc}
\hline & Square-root scale & OECD scale \\
\hline All & 0.1 & 0.1 \\
\hline By ethnic origin: & & \\
Norway & 0.1 & 0.1 \\
Nordic country & 0.5 & 0.5 \\
Western country** & 1.7 & 1.6 \\
Eastern Europe & 1.1 & 1.0 \\
Asia (incl. Turkey) & 1.3 & 1.2 \\
Africa & 1.8 & 1.7 \\
South and Central American & 1.0 & 0.9 \\
\hline
\end{tabular}

*Age 16-68, not in education

**Western Europe (non-Nordic), North America, Australia and New Zealand 
Table A.3. Regression Results for Probability of Being Poor in 1997 by Ethnic Group. Square-root scale

\begin{tabular}{|c|c|c|c|c|c|c|c|}
\hline & Natives & Nordic & Western & $\begin{array}{c}\text { Eastern } \\
\text { European }\end{array}$ & Asian & African & $\begin{array}{l}\text { South or } \\
\text { Central } \\
\text { American }\end{array}$ \\
\hline Intercept & $\begin{array}{r}0.8160 \\
(0.0621)\end{array}$ & $\begin{array}{r}0.2846 \\
(0.3229)\end{array}$ & $\begin{array}{r}1.0879 \\
(0.2638)\end{array}$ & $\begin{array}{r}1.0320 \\
(0.2698)\end{array}$ & $\begin{array}{r}-0.0146 \\
(0.1643)\end{array}$ & $\begin{array}{r}-2.0494 \\
(25.5746)\end{array}$ & $\begin{array}{r}1.1454 \\
(0.4771)\end{array}$ \\
\hline Age & $\begin{array}{r}-0.2051 \\
(0.00296)\end{array}$ & $\begin{array}{r}-0.1536 \\
(0.0153)\end{array}$ & $\begin{array}{r}-0.1428 \\
(0.0126)\end{array}$ & $\begin{array}{r}-0.1278 \\
(0.0114)\end{array}$ & $\begin{array}{r}-0.0782 \\
(0.00765)\end{array}$ & $\begin{array}{r}-0.0184 \\
(0.0186)\end{array}$ & $\begin{array}{r}-0.1382 \\
(0.0240)\end{array}$ \\
\hline $\mathrm{Age}^{2}$ & $\begin{array}{r}0.00217 \\
(0.000036)\end{array}$ & $\begin{array}{r}-0.00198 \\
(0.000184)\end{array}$ & $\begin{array}{r}0.00181 \\
(0.000150)\end{array}$ & $\begin{array}{r}0.00167 \\
(0.000134)\end{array}$ & $\begin{array}{r}0.00104 \\
(0.000093)\end{array}$ & $\begin{array}{r}0.000349 \\
(0.000237)\end{array}$ & $\begin{array}{r}0.00177 \\
(0.000297)\end{array}$ \\
\hline Female & $\begin{array}{r}0.0969 \\
(0.00624)\end{array}$ & $\begin{array}{r}-0.1243 \\
(0.0276)\end{array}$ & $\begin{array}{r}0.0956 \\
(0.0226)\end{array}$ & $\begin{array}{r}0.0321 \\
(0.0235)\end{array}$ & $\begin{array}{r}-0.0500 \\
(0.0154)\end{array}$ & $\begin{array}{r}-0.0471 \\
(0.0362)\end{array}$ & $\begin{array}{r}0.0173 \\
(0.0536)\end{array}$ \\
\hline Single & $\begin{array}{r}1.2729 \\
(0.0243)\end{array}$ & $\begin{array}{r}0.5977 \\
(0.1074)\end{array}$ & $\begin{array}{r}1.1411 \\
(0.0799)\end{array}$ & $\begin{array}{r}1.1515 \\
(0.1435)\end{array}$ & $\begin{array}{r}1.2502 \\
(0.0784)\end{array}$ & $\begin{array}{r}2.8526 \\
(25.5724)\end{array}$ & $\begin{array}{r}1.4074 \\
(0.1301)\end{array}$ \\
\hline $\begin{array}{l}\text { Couple, child } \\
\text { under } 7\end{array}$ & $\begin{array}{r}-0.7431 \\
(0.0272)\end{array}$ & $\begin{array}{r}-0.3425 \\
(0.1113)\end{array}$ & $\begin{array}{r}-0.7455 \\
(0.0834)\end{array}$ & $\begin{array}{r}-0.4414 \\
(0.1429)\end{array}$ & $\begin{array}{r}0.3316 \\
(0.0759)\end{array}$ & $\begin{array}{r}1.1126 \\
(25.5724)\end{array}$ & $\begin{array}{r}-0.5810 \\
(0.1405)\end{array}$ \\
\hline Couple, child 7+ & $\begin{array}{r}-1.7449 \\
(0.0303)\end{array}$ & $\begin{array}{r}-0.8808 \\
(0.1287)\end{array}$ & $\begin{array}{r}-0.6994 \\
(0.0880)\end{array}$ & $\begin{array}{r}-0.6369 \\
(0.1438)\end{array}$ & $\begin{array}{r}-0.4300 \\
(0.0782)\end{array}$ & $\begin{array}{r}1.0115 \\
(25.5725)\end{array}$ & $\begin{array}{r}-0.7538 \\
(0.1573)\end{array}$ \\
\hline $\begin{array}{r}\text { Single mother, } \\
\text { child under } 7\end{array}$ & $\begin{array}{r}1.5407 \\
(0.0294)\end{array}$ & $\begin{array}{r}1.1521 \\
(0.1501)\end{array}$ & $\begin{array}{r}0.6115 \\
(0.1752)\end{array}$ & $\begin{array}{r}0.4714 \\
(0.1777)\end{array}$ & $\begin{array}{r}0.0846 \\
(0.1063)\end{array}$ & $\begin{array}{r}1.5518 \\
(25.5726)\end{array}$ & $\begin{array}{r}0.5393 \\
(0.1901)\end{array}$ \\
\hline $\begin{array}{l}\text { Single mother, } \\
\text { child } 7+\end{array}$ & $\begin{array}{r}0.0407 \\
(0.0300)\end{array}$ & $\begin{array}{r}0.6978 \\
(0.1446)\end{array}$ & $\begin{array}{r}0.6188 \\
(0.1214)\end{array}$ & $\begin{array}{r}0.1019 \\
(0.1632)\end{array}$ & $\begin{array}{r}-0.0627 \\
(0.0985)\end{array}$ & $\begin{array}{r}1.2229 \\
(25.5728)\end{array}$ & $\begin{array}{r}-0.0366 \\
(0.1925)\end{array}$ \\
\hline Single father & $\begin{array}{r}-0.5068 \\
(0.0485)\end{array}$ & $\begin{array}{r}0.0977 \\
(0.2294)\end{array}$ & $\begin{array}{r}0.2149 \\
(0.1833)\end{array}$ & $\begin{array}{r}0.6123 \\
(0.2258)\end{array}$ & $\begin{array}{r}0.1653 \\
(0.1378)\end{array}$ & $\begin{array}{r}1.2593 \\
(25.5731)\end{array}$ & $\begin{array}{r}0.0928 \\
(0.3426)\end{array}$ \\
\hline Other hh type & $\begin{array}{r}0.9000 \\
(0.1525)\end{array}$ & $\begin{array}{r}-0.4343 \\
(0.6493)\end{array}$ & $\begin{array}{l}-0.6076 \\
(0.4298)\end{array}$ & $\begin{array}{r}-1.1649 \\
(0.9242)\end{array}$ & $\begin{array}{r}-0.5728 \\
(0.4807)\end{array}$ & $\begin{array}{r}-10.3874 \\
(179.0)\end{array}$ & $\begin{array}{r}-0.3567 \\
(0.5732)\end{array}$ \\
\hline $\begin{array}{l}\text { Middle school } \\
\text { or less }\end{array}$ & $\begin{array}{r}0.0182 \\
(0.0659)\end{array}$ & $\begin{array}{r}0.1628 \\
(0.2302)\end{array}$ & $\begin{array}{r}0.1077 \\
(0.2047)\end{array}$ & $\begin{array}{r}0.4174 \\
(0.2069)\end{array}$ & $\begin{array}{r}0.3845 \\
(0.0512)\end{array}$ & $\begin{array}{r}-0.0447 \\
(0.1363)\end{array}$ & $\begin{array}{r}0.1446 \\
(0.2194)\end{array}$ \\
\hline $\begin{array}{l}\text { Education after } \\
\text { high school }\end{array}$ & $\begin{array}{r}-0.2013 \\
(0.0199)\end{array}$ & $\begin{array}{l}-0.1114 \\
(0.1266)\end{array}$ & $\begin{array}{r}-0.2559 \\
(0.0966)\end{array}$ & $\begin{array}{r}0.1011 \\
(0.1168)\end{array}$ & $\begin{array}{r}-0.1547 \\
(0.0636)\end{array}$ & $\begin{array}{l}-0.1741 \\
(0.1148)\end{array}$ & $\begin{array}{r}-0.0849 \\
(0.1694)\end{array}$ \\
\hline $\begin{array}{l}\text { College/university } \\
\text { first degree }\end{array}$ & $\begin{array}{r}-0.5299 \\
(0.0208)\end{array}$ & $\begin{array}{r}-0.6826 \\
(0.1486)\end{array}$ & $\begin{array}{r}-0.3085 \\
(0.0925)\end{array}$ & $\begin{array}{r}-0.2456 \\
(0.1304)\end{array}$ & $\begin{array}{r}-0.3169 \\
(0.0598)\end{array}$ & $\begin{array}{r}-0.1833 \\
(0.1172)\end{array}$ & $\begin{array}{r}-0.2917 \\
(0.1831)\end{array}$ \\
\hline $\begin{array}{l}\text { College/university } \\
\text { second degree }\end{array}$ & $\begin{array}{r}-0.5590 \\
(0.0274)\end{array}$ & $\begin{array}{r}-0.4338 \\
(0.1656)\end{array}$ & $\begin{array}{r}-0.5851 \\
(0.1050)\end{array}$ & $\begin{array}{r}0.5554 \\
(0.1276)\end{array}$ & $\begin{array}{r}-0.3196 \\
(0.0736)\end{array}$ & $\begin{array}{r}0.4069 \\
(0.1154)\end{array}$ & $\begin{array}{r}-0.3395 \\
(0.2201)\end{array}$ \\
\hline Edu not available & $\begin{array}{r}1.3452 \\
(0.0251)\end{array}$ & $\begin{array}{r}0.9121 \\
(0.0789)\end{array}$ & $\begin{array}{r}0.9955 \\
(0.0621)\end{array}$ & $\begin{array}{r}0.2663 \\
(0.0721)\end{array}$ & $\begin{array}{r}0.5255 \\
(0.0312)\end{array}$ & $\begin{array}{r}0.1503 \\
(0.0644)\end{array}$ & $\begin{array}{r}0.6862 \\
(0.1029)\end{array}$ \\
\hline $\begin{array}{l}\text { Years since } \\
\text { migration } \\
\text { (YSM) }\end{array}$ & -- & $\begin{array}{r}-0.0474 \\
(0.00991)\end{array}$ & $\begin{array}{r}-0.0513 \\
(0.00828)\end{array}$ & $\begin{array}{l}-0.0700 \\
(0.0125)\end{array}$ & $\begin{array}{r}-0.0360 \\
(0.00745)\end{array}$ & $\begin{array}{r}-0.1046 \\
(0.0148)\end{array}$ & $\begin{array}{l}-0.0890 \\
(0.0231)\end{array}$ \\
\hline $\mathrm{YSM}^{2}$ & -- & $\begin{array}{r}0.000365 \\
(0.000275)\end{array}$ & $\begin{array}{r}-0.00021 \\
(0.000234)\end{array}$ & $\begin{array}{r}-\mathrm{j} 0.00013 \\
(0.000370)\end{array}$ & $\begin{array}{r}0.000255 \\
(0.000250)\end{array}$ & $\begin{array}{r}0.00142 \\
(0.000483)\end{array}$ & $\begin{array}{r}0.000790 \\
(0.000754)\end{array}$ \\
\hline $\begin{array}{l}\text { Number of } \\
\text { observations }\end{array}$ & 1337022 & 34371 & 22812 & 16493 & 36583 & 8358 & 4660 \\
\hline
\end{tabular}

Standard deviation listed in parentheses.

The following categories are references for dummy variables: household type—couple, no children; education—high school. 
Table A.4. Regression Results for Probability of Being Poor in 1997 by Ethnic Group. OECD scale

\begin{tabular}{|c|c|c|c|c|c|c|c|}
\hline & Natives & Nordic & Western & $\begin{array}{r}\text { Eastern } \\
\text { European }\end{array}$ & Asian & African & $\begin{array}{r}\text { South or } \\
\text { Central } \\
\text { American }\end{array}$ \\
\hline Intercept & $\begin{array}{r}-0.2388 \\
(0.0695)\end{array}$ & $\begin{array}{r}0.1880 \\
(0.3414)\end{array}$ & $\begin{array}{r}1.0242 \\
(0.2663)\end{array}$ & $\begin{array}{r}0.2153 \\
(0.2693)\end{array}$ & $\begin{array}{r}-0.5572 \\
(0.1582)\end{array}$ & $\begin{array}{r}-2.7634 \\
(25.4330)\end{array}$ & $\begin{array}{r}1.4103 \\
(0.4850)\end{array}$ \\
\hline Age & $\begin{array}{r}-0.1589 \\
(0.00337)\end{array}$ & $\begin{array}{r}-0.1512 \\
(0.0162)\end{array}$ & $\begin{array}{r}-0.1453 \\
(0.0127)\end{array}$ & $\begin{array}{r}-0.0925 \\
(0.0114)\end{array}$ & $\begin{array}{r}-0.0651 \\
(0.00730)\end{array}$ & $\begin{array}{r}0.00578 \\
(0.0181)\end{array}$ & $\begin{array}{r}-0.1521 \\
(0.0245)\end{array}$ \\
\hline $\mathrm{Age}^{2}$ & $\begin{array}{r}0.00165 \\
(0.000041)\end{array}$ & $\begin{array}{r}0.00193 \\
(0.000196)\end{array}$ & $\begin{array}{r}0.00184 \\
(0.000151)\end{array}$ & $\begin{array}{r}0.00120 \\
(0.000134)\end{array}$ & $\begin{array}{r}0.00086 \\
(0.000089)\end{array}$ & $\begin{array}{r}0.000014 \\
(0.000232)\end{array}$ & $\begin{array}{r}0.00188 \\
(0.000306)\end{array}$ \\
\hline Female & $\begin{array}{r}0.0406 \\
(0.00693)\end{array}$ & $\begin{array}{r}-0.1218 \\
(0.0287)\end{array}$ & $\begin{array}{r}0.0880 \\
(0.0227)\end{array}$ & $\begin{array}{r}0.0172 \\
(0.0225)\end{array}$ & $\begin{array}{r}-0.0376 \\
(0.0142)\end{array}$ & $\begin{array}{r}-0.00889 \\
(0.0337)\end{array}$ & $\begin{array}{r}-0.0217 \\
(0.0536)\end{array}$ \\
\hline Single & $\begin{array}{r}0.8306 \\
(0.0258)\end{array}$ & $\begin{array}{r}0.3035 \\
(0.1102)\end{array}$ & $\begin{array}{r}1.0207 \\
(0.0858)\end{array}$ & $\begin{array}{r}0.7608 \\
(0.1453)\end{array}$ & $\begin{array}{r}0.8239 \\
(0.0792)\end{array}$ & $\begin{array}{r}2.3672 \\
(25.4309)\end{array}$ & $\begin{array}{r}1.1244 \\
(0.1357)\end{array}$ \\
\hline $\begin{array}{l}\text { Couple, child } \\
\text { under } 7\end{array}$ & $\begin{array}{r}-0.2476 \\
(0.0270)\end{array}$ & $\begin{array}{r}-0.1552 \\
(0.1117)\end{array}$ & $\begin{array}{r}-0.5515 \\
(0.0882)\end{array}$ & $\begin{array}{r}0.1449 \\
(0.1424)\end{array}$ & $\begin{array}{r}0.1519 \\
(0.0755)\end{array}$ & $\begin{array}{r}1.6365 \\
(25.4308)\end{array}$ & $\begin{array}{r}-0.1347 \\
(0.1382)\end{array}$ \\
\hline Couple, child 7+ & $\begin{array}{l}-1.1367 \\
(0.0289)\end{array}$ & $\begin{array}{r}-0.5322 \\
(0.1263)\end{array}$ & $\begin{array}{r}-0.4213 \\
(0.0918)\end{array}$ & $\begin{array}{l}0.00808 \\
(0.1428)\end{array}$ & $\begin{array}{r}0.1859 \\
(0.0769)\end{array}$ & $\begin{array}{r}1.5233 \\
(25.4309)\end{array}$ & $\begin{array}{r}-0.3729 \\
(0.1545)\end{array}$ \\
\hline $\begin{array}{l}\text { Single mother, } \\
\text { child under } 7\end{array}$ & $\begin{array}{r}1.0337 \\
(0.0337)\end{array}$ & $\begin{array}{r}0.9397 \\
(0.1573)\end{array}$ & $\begin{array}{r}0.4492 \\
(0.1847)\end{array}$ & $\begin{array}{r}0.0194 \\
(0.1912)\end{array}$ & $\begin{array}{r}-0.2719 \\
(0.1130)\end{array}$ & $\begin{array}{r}1.1236 \\
(25.4311)\end{array}$ & $\begin{array}{r}0.0789 \\
(0.2177)\end{array}$ \\
\hline $\begin{array}{l}\text { Single mother, } \\
\text { child } 7+\end{array}$ & $\begin{array}{r}-0.1218 \\
(0.0330)\end{array}$ & $\begin{array}{r}0.5284 \\
(0.1543)\end{array}$ & $\begin{array}{r}0.6886 \\
(0.1269)\end{array}$ & $\begin{array}{r}0.0264 \\
(0.1676)\end{array}$ & $\begin{array}{r}0.2082 \\
(0.1007)\end{array}$ & $\begin{array}{r}1.1819 \\
(25.4312)\end{array}$ & $\begin{array}{r}-0.1330 \\
(0.2109)\end{array}$ \\
\hline Single father & $\begin{array}{r}-0.5816 \\
(0.0538)\end{array}$ & $\begin{array}{r}0.1218 \\
(0.2392)\end{array}$ & $\begin{array}{r}0.0947 \\
(0.1971)\end{array}$ & $\begin{array}{r}0.2479 \\
(0.2468)\end{array}$ & $\begin{array}{r}0.0358 \\
(0.1420)\end{array}$ & $\begin{array}{r}1.2178 \\
(25.4316)\end{array}$ & $\begin{array}{r}-0.0526 \\
(0.3793)\end{array}$ \\
\hline Other hh type & $\begin{array}{r}1.0034 \\
(0.1560)\end{array}$ & $\begin{array}{c}-0.3016 \\
(0.6513)\end{array}$ & $\begin{array}{c}-0.7597 \\
(0.4719)\end{array}$ & $\begin{array}{c}-0.9983 \\
(0.9231)\end{array}$ & $\begin{array}{c}-0.4441 \\
(0.4806)\end{array}$ & $\begin{array}{r}-10.2292 \\
(178.0)\end{array}$ & $\begin{array}{r}-0.2104 \\
(0.5738)\end{array}$ \\
\hline $\begin{array}{l}\text { Middle school or } \\
\text { less }\end{array}$ & $\begin{array}{r}0.0770 \\
(0.0792)\end{array}$ & $\begin{array}{r}-0.0145 \\
(0.2755)\end{array}$ & $\begin{array}{r}0.1353 \\
(0.2066)\end{array}$ & $\begin{array}{r}0.4189 \\
(0.2130)\end{array}$ & $\begin{array}{r}0.5696 \\
(0.0460)\end{array}$ & $\begin{array}{r}0.1810 \\
(0.1179)\end{array}$ & $\begin{array}{r}0.2437 \\
(0.2267)\end{array}$ \\
\hline $\begin{array}{l}\text { Education after } \\
\text { high school }\end{array}$ & $\begin{array}{r}-0.2285 \\
(0.0230)\end{array}$ & $\begin{array}{r}0.0937 \\
(0.1337)\end{array}$ & $\begin{array}{r}-0.3127 \\
(0.1021)\end{array}$ & $\begin{array}{r}0.1221 \\
(0.1193)\end{array}$ & $\begin{array}{r}-0.2128 \\
(0.0601)\end{array}$ & $\begin{array}{r}-0.1924 \\
(0.1111)\end{array}$ & $\begin{array}{r}-0.0217 \\
(0.1743)\end{array}$ \\
\hline $\begin{array}{l}\text { College/university } \\
\text { first degree }\end{array}$ & $\begin{array}{r}-0.6389 \\
(0.0245)\end{array}$ & $\begin{array}{r}-0.6521 \\
(0.1627)\end{array}$ & $\begin{array}{r}-0.2453 \\
(0.0929)\end{array}$ & $\begin{array}{r}-0.2651 \\
(0.1342)\end{array}$ & $\begin{array}{r}-0.4172 \\
(0.0580)\end{array}$ & $\begin{array}{r}-0.3227 \\
(0.1152)\end{array}$ & $\begin{array}{r}-0.1772 \\
(0.1852)\end{array}$ \\
\hline $\begin{array}{l}\text { College/university } \\
\text { second degree }\end{array}$ & $\begin{array}{r}-0.5652 \\
(0.0307)\end{array}$ & $\begin{array}{r}-0.5007 \\
(0.1882)\end{array}$ & $\begin{array}{r}-0.636 \\
(0.1098)\end{array}$ & $\begin{array}{r}-0.6106 \\
(0.1327)\end{array}$ & $\begin{array}{r}-0.4430 \\
(0.0723)\end{array}$ & $\begin{array}{r}0.2890 \\
(0.1111)\end{array}$ & $\begin{array}{r}-0.5026 \\
(0.2495)\end{array}$ \\
\hline Not available & $\begin{array}{r}1.4524 \\
(0.0275)\end{array}$ & $\begin{array}{r}0.9663 \\
(0.0886)\end{array}$ & $\begin{array}{r}0.9986 \\
(0.0630)\end{array}$ & $\begin{array}{r}0.3409 \\
(0.0729)\end{array}$ & $\begin{array}{r}0.6652 \\
(0.0292)\end{array}$ & $\begin{array}{r}0.2747 \\
(0.0603)\end{array}$ & $\begin{array}{r}0.5843 \\
(0.1094)\end{array}$ \\
\hline $\begin{array}{l}\text { Years since } \\
\text { migration } \\
\text { (YSM) }\end{array}$ & - & $\begin{array}{l}-0.0604 \\
(0.0106)\end{array}$ & -0.0479 & $\begin{array}{l}-0.0735 \\
(0.0125)\end{array}$ & -0.0121 & -0.0671 & $\begin{array}{l}-0.0958 \\
(0.0242)\end{array}$ \\
\hline $\mathrm{YSM}^{2}$ & - & $\begin{array}{r}0.000581 \\
(0.000299)\end{array}$ & $\begin{array}{r}-0.00038 \\
(0.000243)\end{array}$ & $\begin{array}{r}0.000093 \\
(0.000387)\end{array}$ & $\begin{array}{r}-0.00006 \\
(0.000236)\end{array}$ & $\begin{array}{r}0.000839 \\
(0.000461)\end{array}$ & $\begin{array}{r}0.000883 \\
(0.000810)\end{array}$ \\
\hline $\begin{array}{l}\text { Number of } \\
\text { observations }\end{array}$ & 1337022 & 34371 & 22812 & 16493 & 36583 & 8358 & 4660 \\
\hline
\end{tabular}

Standard deviation listed in parentheses.

The following categories are references for dummy variables: household type — couple, no children; education—high school. 
Table A.5. Descriptive Statistics on Age, Years since Migration and Age at Migration by Ethnic Group in the Working Age Population

\begin{tabular}{|c|c|c|c|c|c|c|}
\hline & \multicolumn{2}{|c|}{ Age } & \multicolumn{2}{|c|}{$\begin{array}{c}\text { Years since } \\
\text { Migration }\end{array}$} & \multicolumn{2}{|c|}{$\begin{array}{c}\text { Age at } \\
\text { Migration* }\end{array}$} \\
\hline & Mean & Std. Dev. & Mean & Std. Dev. & Mean & Std. Dev. \\
\hline Norwegian & 42.6 & 13.1 & - & - & - & - \\
\hline All immigrants & 40.2 & 12.0 & 13.9 & 10.5 & 26.3 & 9.8 \\
\hline \multicolumn{7}{|l|}{ Immigrants by ethnic group: } \\
\hline Nordic & 44.0 & 12.4 & 17.7 & 12.6 & 25.3 & 9.1 \\
\hline Western & 44.7 & 11.9 & 17.7 & 12.2 & 26.9 & 8.9 \\
\hline Eastern European & 40.1 & 12.1 & 9.9 & 9.4 & 30.2 & 11.7 \\
\hline Asian & 36.7 & 10.6 & 12.0 & 7.2 & 24.7 & 9.8 \\
\hline African & 35.6 & 10.0 & 11.1 & 7.8 & 24.5 & 8.0 \\
\hline South or Central American & 38.6 & 10.9 & 12.3 & 7.4 & 26.3 & 9.3 \\
\hline
\end{tabular}

*Age at migration is age-YSM-1, due to the fact that the first year in the country counts as one year.

The observations used to the calculate these statistics are the same as for the regression results. The total number of observations are therefore the same as in Tables A.1 and A.2. 
Table A.6. Regression Results for Chronic Poverty by Ethnic Group. Square-root scale

\begin{tabular}{|c|c|c|c|c|c|c|c|}
\hline & Natives & Nordic & Western & $\begin{array}{r}\text { Eastern } \\
\text { European }\end{array}$ & Asian & African & $\begin{array}{r}\text { South or } \\
\text { Central } \\
\text { American }\end{array}$ \\
\hline Intercept & $\begin{array}{r}-0.4400 \\
(0.0783)\end{array}$ & $\begin{array}{r}0.2702 \\
(0.4890)\end{array}$ & $\begin{array}{r}1.5856 \\
(0.3708)\end{array}$ & $\begin{array}{r}-0.3540 \\
(26.9209)\end{array}$ & $\begin{array}{r}0.0976 \\
(0.1847)\end{array}$ & $\begin{array}{r}-0.3069 \\
(33.6099)\end{array}$ & $\begin{array}{r}1.4899 \\
(0.5920\end{array}$ \\
\hline Age & $\begin{array}{r}-0.1690 \\
(0.00376)\end{array}$ & $\begin{array}{r}-0.2002 \\
(0.0228)\end{array}$ & $\begin{array}{r}-0.1965 \\
(0.0176)\end{array}$ & $\begin{array}{r}-0.1179 \\
(0.0134)\end{array}$ & $\begin{array}{r}-0.0931 \\
(0.00895)\end{array}$ & $\begin{array}{r}-0.1093 \\
(0.0224)\end{array}$ & $\begin{array}{r}-0.1606 \\
(0.0288)\end{array}$ \\
\hline $\mathrm{Age}^{2}$ & $\begin{array}{r}0.00186 \\
(0.000045)\end{array}$ & $\begin{array}{r}0.00249 \\
(0.000262)\end{array}$ & $\begin{array}{r}0.00227 \\
(0.000205)\end{array}$ & $\begin{array}{r}0.00160 \\
(0.000158)\end{array}$ & $\begin{array}{r}0.00119 \\
(0.000109)\end{array}$ & $\begin{array}{r}0.00129 \\
(0.000286)\end{array}$ & $\begin{array}{r}0.00203 \\
(0.000348)\end{array}$ \\
\hline Female & $\begin{array}{r}0.0273 \\
(0.00823)\end{array}$ & $\begin{array}{r}-0.1564 \\
(0.0435)\end{array}$ & $\begin{array}{r}0.0996 \\
(0.0325)\end{array}$ & $\begin{array}{r}0.0175 \\
(0.0265)\end{array}$ & $\begin{array}{r}-0.0314 \\
(0.0182)\end{array}$ & $\begin{array}{r}-0.0221 \\
(0.0451)\end{array}$ & $\begin{array}{r}0.0431 \\
(0.0664)\end{array}$ \\
\hline Single & $\begin{array}{r}1.0539 \\
(0.0281)\end{array}$ & $\begin{array}{r}0.9067 \\
(0.1587)\end{array}$ & $\begin{array}{r}1.1081 \\
(0.1175)\end{array}$ & $\begin{array}{r}2.1216 \\
(26.9195)\end{array}$ & $\begin{array}{r}0.8651 \\
(0.0746)\end{array}$ & $\begin{array}{r}2.3202 \\
(33.6075)\end{array}$ & $\begin{array}{r}1.2242 \\
(0.1570)\end{array}$ \\
\hline $\begin{array}{l}\text { Couple, child } \\
\text { under } 7\end{array}$ & $\begin{array}{r}-0.7803 \\
(0.0334)\end{array}$ & $\begin{array}{r}-0.5331 \\
(0.1739)\end{array}$ & $\begin{array}{r}-0.7359 \\
(0.1263)\end{array}$ & $\begin{array}{r}1.1982 \\
(26.9195)\end{array}$ & $\begin{array}{r}-0.2922 \\
(0.0712)\end{array}$ & $\begin{array}{r}1.0694 \\
(33.6075)\end{array}$ & $\begin{array}{r}-0.8572 \\
(0.1869)\end{array}$ \\
\hline Couple, child 7+ & $\begin{array}{r}-1.9556 \\
(0.0373)\end{array}$ & $\begin{array}{r}-1.3455 \\
(0.2060)\end{array}$ & $\begin{array}{r}-0.6311 \\
(0.1268)\end{array}$ & $\begin{array}{r}0.8748 \\
(26.9195)\end{array}$ & $\begin{array}{r}-0.4167 \\
(0.0738)\end{array}$ & $\begin{array}{r}0.8206 \\
(33.6076)\end{array}$ & $\begin{array}{r}-0.8786 \\
(0.1944)\end{array}$ \\
\hline $\begin{array}{l}\text { Single mother, } \\
\text { child under } 7\end{array}$ & $\begin{array}{r}1.4840 \\
(0.0360)\end{array}$ & $\begin{array}{r}1.4288 \\
(0.2250)\end{array}$ & $\begin{array}{r}0.6796 \\
(0.2258)\end{array}$ & $\begin{array}{r}1.7142 \\
(26.9198)\end{array}$ & $\begin{array}{r}-0.2399 \\
(0.1174)\end{array}$ & $\begin{array}{r}1.3503 \\
(33.6077)\end{array}$ & $\begin{array}{r}0.4291 \\
(0.2230)\end{array}$ \\
\hline $\begin{array}{l}\text { Single mother, } \\
\text { child } 7+\end{array}$ & $\begin{array}{r}0.1560 \\
(0.0349)\end{array}$ & $\begin{array}{r}0.8248 \\
(0.2082)\end{array}$ & $\begin{array}{r}0.7230 \\
(0.1591)\end{array}$ & $\begin{array}{r}1.6005 \\
(26.9197)\end{array}$ & $\begin{array}{r}-0.1771 \\
(0.1019)\end{array}$ & $\begin{array}{r}1.3460 \\
(33.6078)\end{array}$ & $\begin{array}{r}-0.1320 \\
(0.2240)\end{array}$ \\
\hline Single father & $\begin{array}{r}-0.3906 \\
(0.0568)\end{array}$ & $\begin{array}{r}-0.6531 \\
(0.4669)\end{array}$ & $\begin{array}{r}-0.0941 \\
(0.2805)\end{array}$ & $\begin{array}{r}1.3672 \\
(26.9212)\end{array}$ & $\begin{array}{r}-0.1291 \\
(0.1524)\end{array}$ & $\begin{array}{r}1.4376 \\
(33.6081)\end{array}$ & $\begin{array}{r}-0.2030 \\
(0.5497)\end{array}$ \\
\hline Other hh type & $\begin{array}{r}1.2129 \\
(0.1713)\end{array}$ & $\begin{array}{r}-0.1703 \\
(0.9059)\end{array}$ & $\begin{array}{c}-0.7684 \\
(0.6516)\end{array}$ & $\begin{array}{r}-10.0522 \\
(188.4)\end{array}$ & $\begin{array}{r}0.6040 \\
(0.4195)\end{array}$ & $\begin{array}{l}-9.4036 \\
(235.3)\end{array}$ & $\begin{array}{r}0.6594 \\
(0.6314)\end{array}$ \\
\hline $\begin{array}{l}\text { Middle school or } \\
\text { less }\end{array}$ & $\begin{array}{r}0.4200 \\
(0.0670)\end{array}$ & $\begin{array}{r}0.6246 \\
(0.2165)\end{array}$ & $\begin{array}{r}0.1506 \\
(0.2352)\end{array}$ & $\begin{array}{r}0.5994 \\
(0.2197)\end{array}$ & $\begin{array}{r}0.4200 \\
(0.0551)\end{array}$ & $\begin{array}{r}0.0506 \\
(0.1434)\end{array}$ & $\begin{array}{r}-0.0287 \\
(0.2459)\end{array}$ \\
\hline $\begin{array}{l}\text { Education after } \\
\text { high school }\end{array}$ & $\begin{array}{r}-0.2827 \\
(0.0244)\end{array}$ & $\begin{array}{r}-0.3793 \\
(0.1672)\end{array}$ & $\begin{array}{r}-0.3388 \\
(0.1193)\end{array}$ & $\begin{array}{r}0.1194 \\
(0.1374)\end{array}$ & $\begin{array}{r}-0.1087 \\
(0.0706)\end{array}$ & $\begin{array}{r}-0.3047 \\
(0.1359)\end{array}$ & $\begin{array}{r}-0.0764 \\
(0.1907)\end{array}$ \\
\hline $\begin{array}{l}\text { College/university } \\
\text { first degree }\end{array}$ & $\begin{array}{r}-0.8231 \\
(0.0283)\end{array}$ & $\begin{array}{r}-0.6085 \\
(0.1828)\end{array}$ & $\begin{array}{r}-0.3504 \\
(0.1127)\end{array}$ & $\begin{array}{r}-0.4725 \\
(0.1711)\end{array}$ & $\begin{array}{r}-0.3335 \\
(0.0695)\end{array}$ & $\begin{array}{r}-0.2397 \\
(0.1421)\end{array}$ & $\begin{array}{r}-0.1457 \\
(0.2059)\end{array}$ \\
\hline $\begin{array}{l}\text { College/university } \\
\text { second degree }\end{array}$ & $\begin{array}{r}-0.9373 \\
(0.0401)\end{array}$ & $\begin{array}{r}-0.5472 \\
(0.2149)\end{array}$ & $\begin{array}{r}-0.4696 \\
(0.1227)\end{array}$ & $\begin{array}{r}-0.4489 \\
(0.1457)\end{array}$ & $\begin{array}{r}-0.4295 \\
(0.0907)\end{array}$ & $\begin{array}{r}0.5514 \\
(0.1340)\end{array}$ & $\begin{array}{r}-0.3576 \\
(0.2551)\end{array}$ \\
\hline Not available & $\begin{array}{r}1.6116 \\
(0.0278)\end{array}$ & $\begin{array}{r}0.9373 \\
(0.0925)\end{array}$ & $\begin{array}{r}0.9617 \\
(0.0738)\end{array}$ & $\begin{array}{r}0.2981 \\
(0.0865)\end{array}$ & $\begin{array}{r}0.5460 \\
(0.0356)\end{array}$ & $\begin{array}{r}0.1649 \\
(0.0735)\end{array}$ & $\begin{array}{r}0.6228 \\
(0.1157)\end{array}$ \\
\hline $\begin{array}{l}\text { Years since } \\
\text { migration } \\
\text { (YSM) }\end{array}$ & -- & $\begin{array}{r}0.0181 \\
(0.0158)\end{array}$ & $\begin{array}{r}0.00513 \\
(0.0125)\end{array}$ & $\begin{array}{l}-0.1479 \\
(0.0158)\end{array}$ & -0.0180 & $\begin{array}{l}-0.0697 \\
(0.0202)\end{array}$ & $\begin{array}{l}-0.0902 \\
(0.0326)\end{array}$ \\
\hline $\mathrm{YSM}^{2}$ & -- & $\begin{array}{r}-0.00123 \\
(0.000424)\end{array}$ & $\begin{array}{r}-0.00148 \\
(0.000346)\end{array}$ & $\begin{array}{r}0.00199 \\
(0.000452)\end{array}$ & $\begin{array}{r}-0.00027 \\
(0.000338)\end{array}$ & $\begin{array}{r}0.000701 \\
(0.000654)\end{array}$ & $\begin{array}{r}0.000723 \\
(0.00102)\end{array}$ \\
\hline $\begin{array}{l}\text { Number of } \\
\text { observations }\end{array}$ & 1201241 & 18203 & 17464 & 13443 & 28795 & 6201 & 3754 \\
\hline
\end{tabular}

Standard deviation listed in parentheses.

The following categories are references for dummy variables: household type — couple, no children; education—high school. 
Table A.7. Regression Results for Chronic Poverty by Ethnic Group. OECD scale

\begin{tabular}{|c|c|c|c|c|c|c|c|}
\hline & Natives & Nordic & Western & $\begin{array}{r}\text { Eastern } \\
\text { European }\end{array}$ & Asian & African & $\begin{array}{r}\text { South or } \\
\text { Central } \\
\text { American }\end{array}$ \\
\hline Intercept & $\begin{array}{r}-0.9503 \\
(0.0917)\end{array}$ & $\begin{array}{r}-0.2069 \\
(0.5461)\end{array}$ & $\begin{array}{r}1.4874 \\
(0.3838)\end{array}$ & $\begin{array}{r}-1.0727 \\
(27.6067)\end{array}$ & $\begin{array}{r}-0.5146 \\
(0.1882)\end{array}$ & $\begin{array}{r}-1.4977 \\
(37.0847)\end{array}$ & $\begin{array}{r}1.5296 \\
(0.6560)\end{array}$ \\
\hline Age & $\begin{array}{r}-0.1538 \\
(0.00451)\end{array}$ & $\begin{array}{r}-0.1827 \\
(0.0255)\end{array}$ & $\begin{array}{r}-0.1917 \\
(0.0183)\end{array}$ & $\begin{array}{r}-0.0897 \\
(0.0138)\end{array}$ & $\begin{array}{r}-0.0732 \\
(0.00914)\end{array}$ & $\begin{array}{r}-0.0569 \\
(0.0250)\end{array}$ & $\begin{array}{r}-0.1624 \\
(0.0317)\end{array}$ \\
\hline $\mathrm{Age}^{2}$ & $\begin{array}{r}0.00165 \\
(0.000054)\end{array}$ & $\begin{array}{r}0.00230 \\
(0.000294)\end{array}$ & $\begin{array}{r}0.00220 \\
(0.000215)\end{array}$ & $\begin{array}{r}0.00124 \\
(0.000164)\end{array}$ & $\begin{array}{r}0.000918 \\
(0.000112)\end{array}$ & $\begin{array}{r}0.000584 \\
(0.000323)\end{array}$ & $\begin{array}{r}0.00191 \\
(0.000389)\end{array}$ \\
\hline Female & $\begin{array}{r}0.0135 \\
(0.00964)\end{array}$ & $\begin{array}{l}-0.1274 \\
(0.0476)\end{array}$ & $\begin{array}{r}0.0912 \\
(0.0337)\end{array}$ & $\begin{array}{l}0.00839 \\
(0.0265)\end{array}$ & $\begin{array}{r}-0.0183 \\
(0.0182)\end{array}$ & $\begin{array}{r}-0.0257 \\
(0.0477)\end{array}$ & $\begin{array}{r}-0.00022 \\
(0.0718)\end{array}$ \\
\hline Single & $\begin{array}{r}0.7991 \\
(0.0303)\end{array}$ & $\begin{array}{r}0.6887 \\
(0.1756)\end{array}$ & $\begin{array}{r}0.9146 \\
(0.1207)\end{array}$ & $\begin{array}{r}1.8502 \\
(27.6052)\end{array}$ & $\begin{array}{r}0.6313 \\
(0.0777)\end{array}$ & $\begin{array}{r}2.0877 \\
(37.0821)\end{array}$ & $\begin{array}{r}1.0114 \\
(0.1986)\end{array}$ \\
\hline $\begin{array}{l}\text { Couple, child } \\
\text { under } 7\end{array}$ & $\begin{array}{r}-0.3468 \\
(0.0339)\end{array}$ & $\begin{array}{r}-0.2796 \\
(0.1857)\end{array}$ & $\begin{array}{r}-0.5777 \\
(0.1269)\end{array}$ & $\begin{array}{r}1.5277 \\
(27.6052)\end{array}$ & $\begin{array}{r}0.0222 \\
(0.0727)\end{array}$ & $\begin{array}{r}1.3542 \\
(37.0821)\end{array}$ & $\begin{array}{r}-0.4372 \\
(0.2165)\end{array}$ \\
\hline Couple, child 7+ & $\begin{array}{r}-1.3249 \\
(0.0359)\end{array}$ & $\begin{array}{r}-0.8928 \\
(0.2117)\end{array}$ & $\begin{array}{r}-0.3696 \\
(0.1270)\end{array}$ & $\begin{array}{r}1.4240 \\
(27.6052)\end{array}$ & $\begin{array}{r}0.0280 \\
(0.0747)\end{array}$ & $\begin{array}{r}1.0051 \\
(37.0822)\end{array}$ & $\begin{array}{r}-0.1251 \\
(0.2152)\end{array}$ \\
\hline $\begin{array}{r}\text { Single mother, } \\
\text { child under } 7\end{array}$ & $\begin{array}{r}0.8820 \\
(0.0448)\end{array}$ & $\begin{array}{r}0.9574 \\
(0.2658)\end{array}$ & $\begin{array}{r}0.3479 \\
(0.2508)\end{array}$ & $\begin{array}{r}1.4577 \\
(27.6056)\end{array}$ & $\begin{array}{r}-0.6484 \\
(0.1376)\end{array}$ & $\begin{array}{r}0.9867 \\
(37.0824)\end{array}$ & $\begin{array}{r}-0.0150 \\
(0.2949)\end{array}$ \\
\hline $\begin{array}{l}\text { Single mother, } \\
\text { child } 7+\end{array}$ & $\begin{array}{r}-0.1409 \\
(0.0411)\end{array}$ & $\begin{array}{r}0.7958 \\
(0.2320)\end{array}$ & $\begin{array}{r}0.6071 \\
(0.1693)\end{array}$ & $\begin{array}{r}1.3787 \\
(27.6054)\end{array}$ & $\begin{array}{r}-0.3625 \\
(0.1120)\end{array}$ & $\begin{array}{r}1.4494 \\
(37.0824)\end{array}$ & $\begin{array}{r}-0.4412 \\
(0.3061)\end{array}$ \\
\hline Single father & $\begin{array}{r}-0.5704 \\
(0.0697)\end{array}$ & $\begin{array}{r}-1.0436 \\
(0.6407)\end{array}$ & $\begin{array}{r}0.0656 \\
(0.2819)\end{array}$ & $\begin{array}{r}1.0575 \\
(27.6077)\end{array}$ & $\begin{array}{r}-0.2201 \\
(0.1675)\end{array}$ & $\begin{array}{r}1.3153 \\
(37.0829)\end{array}$ & $\begin{array}{r}-0.9004 \\
(0.9080)\end{array}$ \\
\hline Other hh type & $\begin{array}{r}1.4901 \\
(0.1740)\end{array}$ & $\begin{array}{r}0.1022 \\
(0.9094)\end{array}$ & $\begin{array}{r}-0.6698 \\
(0.6526)\end{array}$ & $\begin{array}{r}-9.8712 \\
(193.2)\end{array}$ & $\begin{array}{r}0.8363 \\
(0.4208)\end{array}$ & $\begin{array}{r}-9.2282 \\
(259.6)\end{array}$ & $\begin{array}{r}0.9654 \\
(0.6418)\end{array}$ \\
\hline $\begin{array}{l}\text { Middle school or } \\
\text { less }\end{array}$ & $\begin{array}{r}0.5404 \\
(0.0800)\end{array}$ & $\begin{array}{r}0.5056 \\
(0.2530)\end{array}$ & $\begin{array}{r}0.1542 \\
(0.2482)\end{array}$ & $\begin{array}{r}0.5030 \\
(0.2529)\end{array}$ & $\begin{array}{r}0.3898 \\
(0.0568)\end{array}$ & $\begin{array}{r}-0.0532 \\
(0.1625)\end{array}$ & $\begin{array}{r}-0.0772 \\
(0.2938)\end{array}$ \\
\hline $\begin{array}{l}\text { Education after } \\
\text { high school }\end{array}$ & $\begin{array}{r}-0.2857 \\
(0.0288)\end{array}$ & $\begin{array}{r}-0.3048 \\
(0.1903)\end{array}$ & $\begin{array}{r}-0.2845 \\
(0.1274)\end{array}$ & $\begin{array}{r}0.1626 \\
(0.1526)\end{array}$ & $\begin{array}{r}-0.1275 \\
(0.0734)\end{array}$ & $\begin{array}{r}-0.3017 \\
(0.1516)\end{array}$ & $\begin{array}{r}0.0450 \\
(0.2088)\end{array}$ \\
\hline $\begin{array}{l}\text { College/university } \\
\text { first degree }\end{array}$ & $\begin{array}{r}-0.8509 \\
(0.0337)\end{array}$ & $\begin{array}{r}-0.4847 \\
(0.1966)\end{array}$ & $\begin{array}{r}-0.3079 \\
(0.1179)\end{array}$ & $\begin{array}{r}-0.4316 \\
(0.1904)\end{array}$ & $\begin{array}{r}-0.3703 \\
(0.0732)\end{array}$ & $\begin{array}{r}-0.2306 \\
(0.1563)\end{array}$ & $\begin{array}{r}0.0994 \\
(0.2166)\end{array}$ \\
\hline $\begin{array}{l}\text { College/university } \\
\text { second degree }\end{array}$ & $\begin{array}{r}-0.9504 \\
(0.0468)\end{array}$ & $\begin{array}{r}-0.5485 \\
(0.2443)\end{array}$ & $\begin{array}{r}-0.5040 \\
(0.1322)\end{array}$ & $\begin{array}{r}-0.4853 \\
(0.1642)\end{array}$ & $\begin{array}{r}-0.4442 \\
(0.0949)\end{array}$ & $\begin{array}{r}0.5746 \\
(0.1422)\end{array}$ & $\begin{array}{r}-0.3799 \\
(0.2981)\end{array}$ \\
\hline Not available & $\begin{array}{r}1.6093 \\
(0.0322)\end{array}$ & $\begin{array}{r}0.9222 \\
(0.1042)\end{array}$ & $\begin{array}{r}0.9167 \\
(0.0780)\end{array}$ & $\begin{array}{r}0.3792 \\
(0.0953)\end{array}$ & $\begin{array}{r}0.6371 \\
(0.0365)\end{array}$ & $\begin{array}{r}0.2409 \\
(0.0802)\end{array}$ & $\begin{array}{r}0.4990 \\
(0.1341)\end{array}$ \\
\hline $\begin{array}{l}\text { Years since } \\
\text { migration } \\
\text { (YSM) }\end{array}$ & -- & 0.00766 & $\begin{array}{r}-0.00075 \\
(0.0133)\end{array}$ & $\begin{array}{r}-0.1796 \\
(0.0167)\end{array}$ & -0.0185 & $\begin{array}{r}-0.0818 \\
(0.0217)\end{array}$ & $\begin{array}{l}-0.1194 \\
(0.0370)\end{array}$ \\
\hline $\mathrm{YSM}^{2}$ & -- & $\begin{array}{r}-0.00130 \\
(0.000497)\end{array}$ & $\begin{array}{r}-0.00152 \\
(0.000378)\end{array}$ & $\begin{array}{r}0.00290 \\
(0.000484)\end{array}$ & $\begin{array}{r}-0.00013 \\
(0.000347)\end{array}$ & $\begin{array}{r}0.00130 \\
(0.000711)\end{array}$ & $\begin{array}{r}0.00146 \\
(0.00119)\end{array}$ \\
\hline $\begin{array}{l}\text { Number of } \\
\text { observations }\end{array}$ & 1201241 & 18203 & 17464 & 13443 & 28795 & 6201 & 3754 \\
\hline
\end{tabular}

Standard deviation listed in parentheses.

The following categories are references for dummy variables: household type — couple, no children; education—high school. 
Table A.8.

Percentage of 1986-1990 Immigrant Cohorts Still Residing in Norway as of January $1^{\text {st }}, 1996$ by Employment Status

\begin{tabular}{|c|c|c|c|c|}
\hline & \multirow{2}{*}{$\begin{array}{r}\text { Number of } \\
\text { observations }\end{array}$} & \multicolumn{3}{|c|}{ Percentage residing in Norway as of January $1^{\text {st }}, 1996$} \\
\hline & & All & Men & Women \\
\hline \multicolumn{5}{|l|}{ Employed } \\
\hline Nordic & 3981 & 45.2 & 52.1 & 40.4 \\
\hline Western Europe & 1411 & 72.9 & 74.9 & 69.9 \\
\hline North America & 393 & 61.1 & 54.7 & 68.7 \\
\hline Eastern Europe & 1136 & 96.0 & 95.7 & 96.3 \\
\hline Other regions & 8506 & 96.4 & 96.5 & 96.1 \\
\hline \multicolumn{5}{|l|}{ Unemployed } \\
\hline Nordic & 190 & 51.1 & 44.8 & 58.8 \\
\hline Western Europe & 81 & 84.0 & 78.9 & 95.8 \\
\hline North America & 25 & 76.0 & 75.0 & 76.9 \\
\hline Eastern Europe & 330 & 97.3 & 97.4 & 97.0 \\
\hline Other regions & 3081 & 97.5 & 97.4 & 97.7 \\
\hline \multicolumn{5}{|l|}{ Not in labor force } \\
\hline Nordic & 3238 & 18.3 & 17.4 & 18.9 \\
\hline Western Europe & 1957 & 31.1 & 28.9 & 32.9 \\
\hline North America & 1316 & 23.3 & 23.4 & 23.3 \\
\hline Eastern Europe & 1954 & 55.2 & 42.9 & 67.4 \\
\hline Other regions & 13531 & 77.0 & 70.6 & 84.7 \\
\hline \multicolumn{5}{|l|}{ Unspecified } \\
\hline Nordic & 3960 & 1.7 & 1.7 & 1.7 \\
\hline Western Europe & 1195 & 2.8 & 3.1 & 2.4 \\
\hline North America & 619 & 1.1 & 1.8 & 0.6 \\
\hline Eastern Europe & 779 & 5.8 & 4.3 & 8.4 \\
\hline Other regions & 3174 & 36.2 & 34.8 & 39.1 \\
\hline
\end{tabular}


Table A.6. Regression Results for Chronic Poverty by Ethnic Group. Square-root scale

\begin{tabular}{|c|c|c|c|c|c|c|c|}
\hline & Natives & Nordic & Western & $\begin{array}{r}\text { Eastern } \\
\text { European }\end{array}$ & Asian & African & $\begin{array}{r}\text { South or } \\
\text { Central } \\
\text { American }\end{array}$ \\
\hline Intercept & $\begin{array}{r}-0.4400 \\
(0.0783)\end{array}$ & $\begin{array}{r}0.2702 \\
(0.4890)\end{array}$ & $\begin{array}{r}1.5856 \\
(0.3708)\end{array}$ & $\begin{array}{r}-0.3540 \\
(26.9209)\end{array}$ & $\begin{array}{r}0.0976 \\
(0.1847)\end{array}$ & $\begin{array}{r}-0.3069 \\
(33.6099)\end{array}$ & $\begin{array}{r}1.4899 \\
(0.5920\end{array}$ \\
\hline Age & $\begin{array}{r}-0.1690 \\
(0.00376)\end{array}$ & $\begin{array}{r}-0.2002 \\
(0.0228)\end{array}$ & $\begin{array}{r}-0.1965 \\
(0.0176)\end{array}$ & $\begin{array}{r}-0.1179 \\
(0.0134)\end{array}$ & $\begin{array}{r}-0.0931 \\
(0.00895)\end{array}$ & $\begin{array}{r}-0.1093 \\
(0.0224)\end{array}$ & $\begin{array}{r}-0.1606 \\
(0.0288)\end{array}$ \\
\hline $\mathrm{Age}^{2}$ & $\begin{array}{r}0.00186 \\
(0.000045)\end{array}$ & $\begin{array}{r}0.00249 \\
(0.000262)\end{array}$ & $\begin{array}{r}0.00227 \\
(0.000205)\end{array}$ & $\begin{array}{r}0.00160 \\
(0.000158)\end{array}$ & $\begin{array}{r}0.00119 \\
(0.000109)\end{array}$ & $\begin{array}{r}0.00129 \\
(0.000286)\end{array}$ & $\begin{array}{r}0.00203 \\
(0.000348)\end{array}$ \\
\hline Female & $\begin{array}{r}0.0273 \\
(0.00823)\end{array}$ & $\begin{array}{r}-0.1564 \\
(0.0435)\end{array}$ & $\begin{array}{r}0.0996 \\
(0.0325)\end{array}$ & $\begin{array}{r}0.0175 \\
(0.0265)\end{array}$ & $\begin{array}{r}-0.0314 \\
(0.0182)\end{array}$ & $\begin{array}{r}-0.0221 \\
(0.0451)\end{array}$ & $\begin{array}{r}0.0431 \\
(0.0664)\end{array}$ \\
\hline Single & $\begin{array}{r}1.0539 \\
(0.0281)\end{array}$ & $\begin{array}{r}0.9067 \\
(0.1587)\end{array}$ & $\begin{array}{r}1.1081 \\
(0.1175)\end{array}$ & $\begin{array}{r}2.1216 \\
(26.9195)\end{array}$ & $\begin{array}{r}0.8651 \\
(0.0746)\end{array}$ & $\begin{array}{r}2.3202 \\
(33.6075)\end{array}$ & $\begin{array}{r}1.2242 \\
(0.1570)\end{array}$ \\
\hline $\begin{array}{l}\text { Couple, child } \\
\text { under } 7\end{array}$ & $\begin{array}{r}-0.7803 \\
(0.0334)\end{array}$ & $\begin{array}{r}-0.5331 \\
(0.1739)\end{array}$ & $\begin{array}{r}-0.7359 \\
(0.1263)\end{array}$ & $\begin{array}{r}1.1982 \\
(26.9195)\end{array}$ & $\begin{array}{r}-0.2922 \\
(0.0712)\end{array}$ & $\begin{array}{r}1.0694 \\
(33.6075)\end{array}$ & $\begin{array}{r}-0.8572 \\
(0.1869)\end{array}$ \\
\hline Couple, child 7+ & $\begin{array}{r}-1.9556 \\
(0.0373)\end{array}$ & $\begin{array}{r}-1.3455 \\
(0.2060)\end{array}$ & $\begin{array}{r}-0.6311 \\
(0.1268)\end{array}$ & $\begin{array}{r}0.8748 \\
(26.9195)\end{array}$ & $\begin{array}{r}-0.4167 \\
(0.0738)\end{array}$ & $\begin{array}{r}0.8206 \\
(33.6076)\end{array}$ & $\begin{array}{r}-0.8786 \\
(0.1944)\end{array}$ \\
\hline $\begin{array}{l}\text { Single mother, } \\
\text { child under } 7\end{array}$ & $\begin{array}{r}1.4840 \\
(0.0360)\end{array}$ & $\begin{array}{r}1.4288 \\
(0.2250)\end{array}$ & $\begin{array}{r}0.6796 \\
(0.2258)\end{array}$ & $\begin{array}{r}1.7142 \\
(26.9198)\end{array}$ & $\begin{array}{r}-0.2399 \\
(0.1174)\end{array}$ & $\begin{array}{r}1.3503 \\
(33.6077)\end{array}$ & $\begin{array}{r}0.4291 \\
(0.2230)\end{array}$ \\
\hline $\begin{array}{l}\text { Single mother, } \\
\text { child } 7+\end{array}$ & $\begin{array}{r}0.1560 \\
(0.0349)\end{array}$ & $\begin{array}{r}0.8248 \\
(0.2082)\end{array}$ & $\begin{array}{r}0.7230 \\
(0.1591)\end{array}$ & $\begin{array}{r}1.6005 \\
(26.9197)\end{array}$ & $\begin{array}{r}-0.1771 \\
(0.1019)\end{array}$ & $\begin{array}{r}1.3460 \\
(33.6078)\end{array}$ & $\begin{array}{r}-0.1320 \\
(0.2240)\end{array}$ \\
\hline Single father & $\begin{array}{r}-0.3906 \\
(0.0568)\end{array}$ & $\begin{array}{r}-0.6531 \\
(0.4669)\end{array}$ & $\begin{array}{r}-0.0941 \\
(0.2805)\end{array}$ & $\begin{array}{r}1.3672 \\
(26.9212)\end{array}$ & $\begin{array}{r}-0.1291 \\
(0.1524)\end{array}$ & $\begin{array}{r}1.4376 \\
(33.6081)\end{array}$ & $\begin{array}{r}-0.2030 \\
(0.5497)\end{array}$ \\
\hline Other hh type & $\begin{array}{r}1.2129 \\
(0.1713)\end{array}$ & $\begin{array}{r}-0.1703 \\
(0.9059)\end{array}$ & $\begin{array}{c}-0.7684 \\
(0.6516)\end{array}$ & $\begin{array}{r}-10.0522 \\
(188.4)\end{array}$ & $\begin{array}{r}0.6040 \\
(0.4195)\end{array}$ & $\begin{array}{l}-9.4036 \\
(235.3)\end{array}$ & $\begin{array}{r}0.6594 \\
(0.6314)\end{array}$ \\
\hline $\begin{array}{l}\text { Middle school or } \\
\text { less }\end{array}$ & $\begin{array}{r}0.4200 \\
(0.0670)\end{array}$ & $\begin{array}{r}0.6246 \\
(0.2165)\end{array}$ & $\begin{array}{r}0.1506 \\
(0.2352)\end{array}$ & $\begin{array}{r}0.5994 \\
(0.2197)\end{array}$ & $\begin{array}{r}0.4200 \\
(0.0551)\end{array}$ & $\begin{array}{r}0.0506 \\
(0.1434)\end{array}$ & $\begin{array}{r}-0.0287 \\
(0.2459)\end{array}$ \\
\hline $\begin{array}{l}\text { Education after } \\
\text { high school }\end{array}$ & $\begin{array}{r}-0.2827 \\
(0.0244)\end{array}$ & $\begin{array}{r}-0.3793 \\
(0.1672)\end{array}$ & $\begin{array}{r}-0.3388 \\
(0.1193)\end{array}$ & $\begin{array}{r}0.1194 \\
(0.1374)\end{array}$ & $\begin{array}{r}-0.1087 \\
(0.0706)\end{array}$ & $\begin{array}{r}-0.3047 \\
(0.1359)\end{array}$ & $\begin{array}{r}-0.0764 \\
(0.1907)\end{array}$ \\
\hline $\begin{array}{l}\text { College/university } \\
\text { first degree }\end{array}$ & $\begin{array}{r}-0.8231 \\
(0.0283)\end{array}$ & $\begin{array}{r}-0.6085 \\
(0.1828)\end{array}$ & $\begin{array}{r}-0.3504 \\
(0.1127)\end{array}$ & $\begin{array}{r}-0.4725 \\
(0.1711)\end{array}$ & $\begin{array}{r}-0.3335 \\
(0.0695)\end{array}$ & $\begin{array}{r}-0.2397 \\
(0.1421)\end{array}$ & $\begin{array}{r}-0.1457 \\
(0.2059)\end{array}$ \\
\hline $\begin{array}{l}\text { College/university } \\
\text { second degree }\end{array}$ & $\begin{array}{r}-0.9373 \\
(0.0401)\end{array}$ & $\begin{array}{r}-0.5472 \\
(0.2149)\end{array}$ & $\begin{array}{r}-0.4696 \\
(0.1227)\end{array}$ & $\begin{array}{r}-0.4489 \\
(0.1457)\end{array}$ & $\begin{array}{r}-0.4295 \\
(0.0907)\end{array}$ & $\begin{array}{r}0.5514 \\
(0.1340)\end{array}$ & $\begin{array}{r}-0.3576 \\
(0.2551)\end{array}$ \\
\hline Not available & $\begin{array}{r}1.6116 \\
(0.0278)\end{array}$ & $\begin{array}{r}0.9373 \\
(0.0925)\end{array}$ & $\begin{array}{r}0.9617 \\
(0.0738)\end{array}$ & $\begin{array}{r}0.2981 \\
(0.0865)\end{array}$ & $\begin{array}{r}0.5460 \\
(0.0356)\end{array}$ & $\begin{array}{r}0.1649 \\
(0.0735)\end{array}$ & $\begin{array}{r}0.6228 \\
(0.1157)\end{array}$ \\
\hline $\begin{array}{l}\text { Years since } \\
\text { migration } \\
\text { (YSM) }\end{array}$ & -- & $\begin{array}{r}0.0181 \\
(0.0158)\end{array}$ & $\begin{array}{r}0.00513 \\
(0.0125)\end{array}$ & $\begin{array}{l}-0.1479 \\
(0.0158)\end{array}$ & -0.0180 & $\begin{array}{l}-0.0697 \\
(0.0202)\end{array}$ & $\begin{array}{l}-0.0902 \\
(0.0326)\end{array}$ \\
\hline $\mathrm{YSM}^{2}$ & -- & $\begin{array}{r}-0.00123 \\
(0.000424)\end{array}$ & $\begin{array}{r}-0.00148 \\
(0.000346)\end{array}$ & $\begin{array}{r}0.00199 \\
(0.000452)\end{array}$ & $\begin{array}{r}-0.00027 \\
(0.000338)\end{array}$ & $\begin{array}{r}0.000701 \\
(0.000654)\end{array}$ & $\begin{array}{r}0.000723 \\
(0.00102)\end{array}$ \\
\hline $\begin{array}{l}\text { Number of } \\
\text { observations }\end{array}$ & 1201241 & 18203 & 17464 & 13443 & 28795 & 6201 & 3754 \\
\hline
\end{tabular}

Standard deviation listed in parentheses.

The following categories are references for dummy variables: household type — couple, no children; education—high school. 
Table A.7. Regression Results for Chronic Poverty by Ethnic Group. OECD scale

\begin{tabular}{|c|c|c|c|c|c|c|c|}
\hline & Natives & Nordic & Western & $\begin{array}{r}\text { Eastern } \\
\text { European }\end{array}$ & Asian & African & $\begin{array}{r}\text { South or } \\
\text { Central } \\
\text { American }\end{array}$ \\
\hline Intercept & $\begin{array}{r}-0.9503 \\
(0.0917)\end{array}$ & $\begin{array}{r}-0.2069 \\
(0.5461)\end{array}$ & $\begin{array}{r}1.4874 \\
(0.3838)\end{array}$ & $\begin{array}{r}-1.0727 \\
(27.6067)\end{array}$ & $\begin{array}{r}-0.5146 \\
(0.1882)\end{array}$ & $\begin{array}{r}-1.4977 \\
(37.0847)\end{array}$ & $\begin{array}{r}1.5296 \\
(0.6560)\end{array}$ \\
\hline Age & $\begin{array}{r}-0.1538 \\
(0.00451)\end{array}$ & $\begin{array}{r}-0.1827 \\
(0.0255)\end{array}$ & $\begin{array}{r}-0.1917 \\
(0.0183)\end{array}$ & $\begin{array}{r}-0.0897 \\
(0.0138)\end{array}$ & $\begin{array}{r}-0.0732 \\
(0.00914)\end{array}$ & $\begin{array}{r}-0.0569 \\
(0.0250)\end{array}$ & $\begin{array}{r}-0.1624 \\
(0.0317)\end{array}$ \\
\hline $\mathrm{Age}^{2}$ & $\begin{array}{r}0.00165 \\
(0.000054)\end{array}$ & $\begin{array}{r}0.00230 \\
(0.000294)\end{array}$ & $\begin{array}{r}0.00220 \\
(0.000215)\end{array}$ & $\begin{array}{r}0.00124 \\
(0.000164)\end{array}$ & $\begin{array}{r}0.000918 \\
(0.000112)\end{array}$ & $\begin{array}{r}0.000584 \\
(0.000323)\end{array}$ & $\begin{array}{r}0.00191 \\
(0.000389)\end{array}$ \\
\hline Female & $\begin{array}{r}0.0135 \\
(0.00964)\end{array}$ & $\begin{array}{l}-0.1274 \\
(0.0476)\end{array}$ & $\begin{array}{r}0.0912 \\
(0.0337)\end{array}$ & $\begin{array}{l}0.00839 \\
(0.0265)\end{array}$ & $\begin{array}{r}-0.0183 \\
(0.0182)\end{array}$ & $\begin{array}{r}-0.0257 \\
(0.0477)\end{array}$ & $\begin{array}{r}-0.00022 \\
(0.0718)\end{array}$ \\
\hline Single & $\begin{array}{r}0.7991 \\
(0.0303)\end{array}$ & $\begin{array}{r}0.6887 \\
(0.1756)\end{array}$ & $\begin{array}{r}0.9146 \\
(0.1207)\end{array}$ & $\begin{array}{r}1.8502 \\
(27.6052)\end{array}$ & $\begin{array}{r}0.6313 \\
(0.0777)\end{array}$ & $\begin{array}{r}2.0877 \\
(37.0821)\end{array}$ & $\begin{array}{r}1.0114 \\
(0.1986)\end{array}$ \\
\hline $\begin{array}{l}\text { Couple, child } \\
\text { under } 7\end{array}$ & $\begin{array}{r}-0.3468 \\
(0.0339)\end{array}$ & $\begin{array}{r}-0.2796 \\
(0.1857)\end{array}$ & $\begin{array}{r}-0.5777 \\
(0.1269)\end{array}$ & $\begin{array}{r}1.5277 \\
(27.6052)\end{array}$ & $\begin{array}{r}0.0222 \\
(0.0727)\end{array}$ & $\begin{array}{r}1.3542 \\
(37.0821)\end{array}$ & $\begin{array}{r}-0.4372 \\
(0.2165)\end{array}$ \\
\hline Couple, child 7+ & $\begin{array}{r}-1.3249 \\
(0.0359)\end{array}$ & $\begin{array}{r}-0.8928 \\
(0.2117)\end{array}$ & $\begin{array}{r}-0.3696 \\
(0.1270)\end{array}$ & $\begin{array}{r}1.4240 \\
(27.6052)\end{array}$ & $\begin{array}{r}0.0280 \\
(0.0747)\end{array}$ & $\begin{array}{r}1.0051 \\
(37.0822)\end{array}$ & $\begin{array}{r}-0.1251 \\
(0.2152)\end{array}$ \\
\hline $\begin{array}{r}\text { Single mother, } \\
\text { child under } 7\end{array}$ & $\begin{array}{r}0.8820 \\
(0.0448)\end{array}$ & $\begin{array}{r}0.9574 \\
(0.2658)\end{array}$ & $\begin{array}{r}0.3479 \\
(0.2508)\end{array}$ & $\begin{array}{r}1.4577 \\
(27.6056)\end{array}$ & $\begin{array}{r}-0.6484 \\
(0.1376)\end{array}$ & $\begin{array}{r}0.9867 \\
(37.0824)\end{array}$ & $\begin{array}{r}-0.0150 \\
(0.2949)\end{array}$ \\
\hline $\begin{array}{l}\text { Single mother, } \\
\text { child } 7+\end{array}$ & $\begin{array}{r}-0.1409 \\
(0.0411)\end{array}$ & $\begin{array}{r}0.7958 \\
(0.2320)\end{array}$ & $\begin{array}{r}0.6071 \\
(0.1693)\end{array}$ & $\begin{array}{r}1.3787 \\
(27.6054)\end{array}$ & $\begin{array}{r}-0.3625 \\
(0.1120)\end{array}$ & $\begin{array}{r}1.4494 \\
(37.0824)\end{array}$ & $\begin{array}{r}-0.4412 \\
(0.3061)\end{array}$ \\
\hline Single father & $\begin{array}{r}-0.5704 \\
(0.0697)\end{array}$ & $\begin{array}{r}-1.0436 \\
(0.6407)\end{array}$ & $\begin{array}{r}0.0656 \\
(0.2819)\end{array}$ & $\begin{array}{r}1.0575 \\
(27.6077)\end{array}$ & $\begin{array}{r}-0.2201 \\
(0.1675)\end{array}$ & $\begin{array}{r}1.3153 \\
(37.0829)\end{array}$ & $\begin{array}{r}-0.9004 \\
(0.9080)\end{array}$ \\
\hline Other hh type & $\begin{array}{r}1.4901 \\
(0.1740)\end{array}$ & $\begin{array}{r}0.1022 \\
(0.9094)\end{array}$ & $\begin{array}{r}-0.6698 \\
(0.6526)\end{array}$ & $\begin{array}{r}-9.8712 \\
(193.2)\end{array}$ & $\begin{array}{r}0.8363 \\
(0.4208)\end{array}$ & $\begin{array}{r}-9.2282 \\
(259.6)\end{array}$ & $\begin{array}{r}0.9654 \\
(0.6418)\end{array}$ \\
\hline $\begin{array}{l}\text { Middle school or } \\
\text { less }\end{array}$ & $\begin{array}{r}0.5404 \\
(0.0800)\end{array}$ & $\begin{array}{r}0.5056 \\
(0.2530)\end{array}$ & $\begin{array}{r}0.1542 \\
(0.2482)\end{array}$ & $\begin{array}{r}0.5030 \\
(0.2529)\end{array}$ & $\begin{array}{r}0.3898 \\
(0.0568)\end{array}$ & $\begin{array}{r}-0.0532 \\
(0.1625)\end{array}$ & $\begin{array}{r}-0.0772 \\
(0.2938)\end{array}$ \\
\hline $\begin{array}{l}\text { Education after } \\
\text { high school }\end{array}$ & $\begin{array}{r}-0.2857 \\
(0.0288)\end{array}$ & $\begin{array}{r}-0.3048 \\
(0.1903)\end{array}$ & $\begin{array}{r}-0.2845 \\
(0.1274)\end{array}$ & $\begin{array}{r}0.1626 \\
(0.1526)\end{array}$ & $\begin{array}{r}-0.1275 \\
(0.0734)\end{array}$ & $\begin{array}{r}-0.3017 \\
(0.1516)\end{array}$ & $\begin{array}{r}0.0450 \\
(0.2088)\end{array}$ \\
\hline $\begin{array}{l}\text { College/university } \\
\text { first degree }\end{array}$ & $\begin{array}{r}-0.8509 \\
(0.0337)\end{array}$ & $\begin{array}{r}-0.4847 \\
(0.1966)\end{array}$ & $\begin{array}{r}-0.3079 \\
(0.1179)\end{array}$ & $\begin{array}{r}-0.4316 \\
(0.1904)\end{array}$ & $\begin{array}{r}-0.3703 \\
(0.0732)\end{array}$ & $\begin{array}{r}-0.2306 \\
(0.1563)\end{array}$ & $\begin{array}{r}0.0994 \\
(0.2166)\end{array}$ \\
\hline $\begin{array}{l}\text { College/university } \\
\text { second degree }\end{array}$ & $\begin{array}{r}-0.9504 \\
(0.0468)\end{array}$ & $\begin{array}{r}-0.5485 \\
(0.2443)\end{array}$ & $\begin{array}{r}-0.5040 \\
(0.1322)\end{array}$ & $\begin{array}{r}-0.4853 \\
(0.1642)\end{array}$ & $\begin{array}{r}-0.4442 \\
(0.0949)\end{array}$ & $\begin{array}{r}0.5746 \\
(0.1422)\end{array}$ & $\begin{array}{r}-0.3799 \\
(0.2981)\end{array}$ \\
\hline Not available & $\begin{array}{r}1.6093 \\
(0.0322)\end{array}$ & $\begin{array}{r}0.9222 \\
(0.1042)\end{array}$ & $\begin{array}{r}0.9167 \\
(0.0780)\end{array}$ & $\begin{array}{r}0.3792 \\
(0.0953)\end{array}$ & $\begin{array}{r}0.6371 \\
(0.0365)\end{array}$ & $\begin{array}{r}0.2409 \\
(0.0802)\end{array}$ & $\begin{array}{r}0.4990 \\
(0.1341)\end{array}$ \\
\hline $\begin{array}{l}\text { Years since } \\
\text { migration } \\
\text { (YSM) }\end{array}$ & -- & 0.00766 & $\begin{array}{r}-0.00075 \\
(0.0133)\end{array}$ & $\begin{array}{r}-0.1796 \\
(0.0167)\end{array}$ & -0.0185 & $\begin{array}{r}-0.0818 \\
(0.0217)\end{array}$ & $\begin{array}{l}-0.1194 \\
(0.0370)\end{array}$ \\
\hline $\mathrm{YSM}^{2}$ & -- & $\begin{array}{r}-0.00130 \\
(0.000497)\end{array}$ & $\begin{array}{r}-0.00152 \\
(0.000378)\end{array}$ & $\begin{array}{r}0.00290 \\
(0.000484)\end{array}$ & $\begin{array}{r}-0.00013 \\
(0.000347)\end{array}$ & $\begin{array}{r}0.00130 \\
(0.000711)\end{array}$ & $\begin{array}{r}0.00146 \\
(0.00119)\end{array}$ \\
\hline $\begin{array}{l}\text { Number of } \\
\text { observations }\end{array}$ & 1201241 & 18203 & 17464 & 13443 & 28795 & 6201 & 3754 \\
\hline
\end{tabular}

Standard deviation listed in parentheses.

The following categories are references for dummy variables: household type — couple, no children; education—high school. 
Table A.8.

Percentage of 1986-1990 Immigrant Cohorts Still Residing in Norway as of January $1^{\text {st }}, 1996$ by Employment Status

\begin{tabular}{|c|c|c|c|c|}
\hline & \multirow{2}{*}{$\begin{array}{r}\text { Number of } \\
\text { observations }\end{array}$} & \multicolumn{3}{|c|}{ Percentage residing in Norway as of January $1^{\text {st }}, 1996$} \\
\hline & & All & Men & Women \\
\hline \multicolumn{5}{|l|}{ Employed } \\
\hline Nordic & 3981 & 45.2 & 52.1 & 40.4 \\
\hline Western Europe & 1411 & 72.9 & 74.9 & 69.9 \\
\hline North America & 393 & 61.1 & 54.7 & 68.7 \\
\hline Eastern Europe & 1136 & 96.0 & 95.7 & 96.3 \\
\hline Other regions & 8506 & 96.4 & 96.5 & 96.1 \\
\hline \multicolumn{5}{|l|}{ Unemployed } \\
\hline Nordic & 190 & 51.1 & 44.8 & 58.8 \\
\hline Western Europe & 81 & 84.0 & 78.9 & 95.8 \\
\hline North America & 25 & 76.0 & 75.0 & 76.9 \\
\hline Eastern Europe & 330 & 97.3 & 97.4 & 97.0 \\
\hline Other regions & 3081 & 97.5 & 97.4 & 97.7 \\
\hline \multicolumn{5}{|l|}{ Not in labor force } \\
\hline Nordic & 3238 & 18.3 & 17.4 & 18.9 \\
\hline Western Europe & 1957 & 31.1 & 28.9 & 32.9 \\
\hline North America & 1316 & 23.3 & 23.4 & 23.3 \\
\hline Eastern Europe & 1954 & 55.2 & 42.9 & 67.4 \\
\hline Other regions & 13531 & 77.0 & 70.6 & 84.7 \\
\hline \multicolumn{5}{|l|}{ Unspecified } \\
\hline Nordic & 3960 & 1.7 & 1.7 & 1.7 \\
\hline Western Europe & 1195 & 2.8 & 3.1 & 2.4 \\
\hline North America & 619 & 1.1 & 1.8 & 0.6 \\
\hline Eastern Europe & 779 & 5.8 & 4.3 & 8.4 \\
\hline Other regions & 3174 & 36.2 & 34.8 & 39.1 \\
\hline
\end{tabular}

